University of Nebraska - Lincoln

DigitalCommons@University of Nebraska - Lincoln

$10-21-2002$

\title{
Environmental controls over carbon dioxide and water vapor exchange of terrestrial vegetation
}

\author{
B. E. Law \\ Oregon State University, bev.law@oregonstate.edu \\ E. Falge \\ Pflanzenökologie, Universität Bayreuth, 95440 Bayreuth, Germany \\ L. Gu \\ University of California, Berkeley \\ D. D. Baldocchi \\ University of California, Berkeley, baldocchi@berkeley.edu \\ P. Bakwin \\ NOAA/OAR, Climate Monitoring and Diagnostics Laboratory, 325 Broadway, Boulder, CO 80303, USA \\ See next page for additional authors
}

Follow this and additional works at: https://digitalcommons.unl.edu/natrespapers

Part of the Natural Resources and Conservation Commons

Law, B. E.; Falge, E.; Gu, L.; Baldocchi, D. D.; Bakwin, P.; Berbigier, P.; Davis, K.; Dolman, A. J.; Falk, M.; Fuentes, J. D.; Goldstein, A.; Granier, A.; Grelle, A.; Hollinger, D.; Janssens, I. A.; Jarvis, P.; Jensen, N. O.; Katul, G.; Mahli, K.; Matteucci, G.; Meyers, T.; Monson, R.; Munger, W.; Oechel, W.; Olson, R.; Pilegaard, K.; Paw U, K. T.; Thorgeirsson, H.; Valentini, R.; Verma, Shashi; Vesala, T.; Wilson, K.; and Wofsy, S., "Environmental controls over carbon dioxide and water vapor exchange of terrestrial vegetation" (2002). Papers in Natural Resources. 65.

https://digitalcommons.unl.edu/natrespapers/65

This Article is brought to you for free and open access by the Natural Resources, School of at DigitalCommons@University of Nebraska - Lincoln. It has been accepted for inclusion in Papers in Natural Resources by an authorized administrator of DigitalCommons@University of Nebraska - Lincoln. 


\section{Authors}

B. E. Law, E. Falge, L. Gu, D. D. Baldocchi, P. Bakwin, P. Berbigier, K. Davis, A. J. Dolman, M. Falk, J. D. Fuentes, A. Goldstein, A. Granier, A. Grelle, D. Hollinger, I. A. Janssens, P. Jarvis, N. O. Jensen, G. Katul, K. Mahli, G. Matteucci, T. Meyers, R. Monson, W. Munger, W. Oechel, R. Olson, K. Pilegaard, K. T. Paw U, H. Thorgeirsson, R. Valentini, Shashi Verma, T. Vesala, K. Wilson, and S. Wofsy 


\section{Environmental controls over carbon dioxide and water vapor exchange of terrestrial vegetation}

B.E. Law ${ }^{\text {a,* }}$, E. Falge ${ }^{\text {b }}$, L. Gu ${ }^{\text {c }}$, D.D. Baldocchi ${ }^{\text {c }}$, P. Bakwin ${ }^{\text {d }}$, P. Berbigier ${ }^{\text {e }}$, K. Davis ${ }^{f}$, A.J. Dolman ${ }^{\text {g }}$, M. Falk ${ }^{\text {h }}$, J.D. Fuentes ${ }^{i}$, A. Goldstein ${ }^{\text {c }}$, A. Granier ${ }^{j}$, A. Grelle $^{\mathrm{k}}$, D. Hollinger ${ }^{1}$, I.A. Janssens ${ }^{\mathrm{m}}$, P. Jarvis ${ }^{\mathrm{n}}$, N.O. Jensen ${ }^{\mathrm{o}}$, G. Katul ${ }^{\mathrm{p}}$, Y. Mahli ${ }^{\mathrm{q}}$, G. Matteucci ${ }^{\mathrm{r}}$, T. Meyers ${ }^{\mathrm{s}}$, R. Monson ${ }^{\mathrm{t}}$, W. Munger ${ }^{\mathrm{u}}$, W. Oechel ${ }^{\mathrm{v}}$, R. Olson ${ }^{\mathrm{w}}$, K. Pilegaard ${ }^{\mathrm{x}}$, K.T. Paw $\mathrm{U}^{\mathrm{h}}$, H. Thorgeirsson ${ }^{\mathrm{y}}$, R. Valentini ${ }^{\mathrm{r}}$, S. Verma ${ }^{\mathrm{z}}$, T. Vesala ${ }^{\mathrm{a}}, \mathrm{K}$. Wilson ${ }^{\mathrm{s}}, \mathrm{S}$. Wofsy ${ }^{\mathrm{u}}$

a 328 Richardson Hall, College of Forestry, Oregon State University, Corvallis, OR 97331-5752, USA

b Pflanzenökologie, Universität Bayreuth, 95440 Bayreuth, Germany

${ }^{\mathrm{c}}$ ESPM, University of California, Berkeley, CA 94704, USA

d NOAA/OAR, Climate Monitoring and Diagnostics Laboratory, 325 Broadway, Boulder, CO 80303, USA

' INRA Centre de Bordeaux, Unite de Bioclimatologie, BP 81, 33833 Villenave d'ornon Cedex, France

${ }^{\mathrm{f}}$ Department of Soil, Water, and Climate, University of Minnesota, St. Paul, MN 55108, USA

${ }^{g}$ Alterra, P.O. Box 47, 6700 AA Wageningen, The Netherlands

${ }^{\mathrm{h}}$ Atmospheric Science Group, LAWR, UC Davis, 122 Hoagland Hall, Davis, CA 95616, USA

${ }^{i}$ Department of Environmental Science, University of Virginia, Charlottesville, VA, USA

${ }^{\mathrm{j}}$ Centre de Recherces de Nancy, Unite Ecophysiologie Forestieres, Equipe Bioclimatologie, 54280 Champenoux, France

${ }^{k}$ Department of Ecology and Environmental Research, Swedish University of Agricultural Sciences, S-750 07 Uppsala, Sweden

${ }^{1}$ USDA Forest Service, 271 Mast Road, Durham, NH 03824, USA

${ }^{\mathrm{m}}$ Department of Biology, University of Antwerpen, Wilrijk, Belgium

${ }^{\mathrm{n}}$ Institute of Ecology and Resource Management, University of Edinburgh, Darwin Building, King's Buildings, Edinburgh EH9 3JU, UK ${ }^{\circ}$ Risoe National Laboratory, DK-4000 Roskilde, Denmark

p School of the Environment, Duke University, Box 90328, Durham, NC 27708-0328, USA

${ }^{\mathrm{q}}$ Institute of Ecology and Resource Management, University of Edinburgh, Darwin Building, King's Buildings, Mayfield Road, Edinburgh EH9 3JU, UK

${ }^{\mathrm{r}}$ Department of Forest Environment and Resources, University of Tuscia, I-01100 Viterbo, Italy

${ }^{\mathrm{s}}$ NOAA/ARL Atmospheric Turbulence and Diffusion Division, 456 South Illinois Avenue, Oak Ridge, TN 37831-2456, USA

${ }^{t}$ Department of Environmental, Population, and Organismic Biology, University of Colorado, Campus Box 334, Boulder, CO 80309, USA

" Department of Earth and Planetary Sciences, Harvard University, 20 Oxford Street, Cambridge, MA 02138, USA

${ }^{v}$ Department of Biology, San Diego State University, San Diego, CA, USA

${ }^{\mathrm{w}}$ Environmental Science Division, Oak Ridge National Laboratory, Oak Ridge, TN, USA

${ }^{x}$ Plant Biology and Biogeochemistry Department, Risoe National Laboratory, P.O. Box 49, DK-4000 Roskilde, Denmark

${ }^{y}$ Department of Environmental Research, Agricultural Research Institute, IS-112 Reykjavik, Iceland

${ }^{\mathrm{z}}$ Department of Agricultural Meteorology, University of Nebraska-Lincoln, 244 L.W. Chase Hall, P.O. Box 830728, Lincoln, NE 68583, USA

${ }^{a 1}$ Department of Physics, University of Helsinki, P.O. Box 9, FIN-00014 Helsinki, Finland

\footnotetext{
* Corresponding author. Tel.: +1-541-737-6111; fax: +1-541-737-1393.

E-mail address: lawb@fsl.orst.edu (B.E. Law).
} 


\begin{abstract}
The objective of this research was to compare seasonal and annual estimates of $\mathrm{CO}_{2}$ and water vapor exchange across sites in forests, grasslands, crops, and tundra that are part of an international network called FLUXNET, and to investigating the responses of vegetation to environmental variables. FLUXNETs goals are to understand the mechanisms controlling the exchanges of $\mathrm{CO}_{2}$, water vapor and energy across a spectrum of time and space scales, and to provide information for modeling of carbon and water cycling across regions and the globe. At a subset of sites, net carbon uptake (net ecosystem exchange, the net of photosynthesis and respiration) was greater under diffuse than under direct radiation conditions, perhaps because of a more efficient distribution of non-saturating light conditions for photosynthesis, lower vapor pressure deficit limitation to photosynthesis, and lower respiration associated with reduced temperature. The slope of the relation between monthly gross ecosystem production and evapotranspiration was similar between biomes, except for tundra vegetation, showing a strong linkage between carbon gain and water loss integrated over the year (slopes $=3.4 \mathrm{~g} \mathrm{CO}_{2} / \mathrm{kg} \mathrm{H}_{2} \mathrm{O}$ for grasslands, 3.2 for deciduous broadleaf forests, 3.1 for crops, 2.4 for evergreen conifers, and 1.5 for tundra vegetation). The ratio of annual ecosystem respiration to gross photosynthesis averaged 0.83 , with lower values for grasslands, presumably because of less investment in respiring plant tissue compared with forests. Ecosystem respiration was weakly correlated with mean annual temperature across biomes, in spite of within site sensitivity over shorter temporal scales. Mean annual temperature and site water balance explained much of the variation in gross photosynthesis. Water availability limits leaf area index over the long-term, and inter-annual climate variability can limit carbon uptake below the potential of the leaf area present.
\end{abstract}

(C) 2002 Elsevier Science B.V. All rights reserved.

Keywords: Gross ecosystem production; Ecosystem respiration; Net ecosystem exchange; Carbon balance; Eddy covariance

\section{Introduction}

The response of vegetation to the environment is a key global change issue that scientists are investigating by means of measurements and models on shortand long-time scales. Previous comparisons of the responses of terrestrial ecosystems of the world to the environment included measurements of aboveground production in relation to temperature, precipitation, and empirical estimates of evapotranspiration (ET). For example, earlier work suggested that annual productivity increased with mean annual temperature and precipitation (Lieth, 1972a,b; O'Neill and DeAngelis, 1981). Concurrently, leaf-level studies suggested a mechanism for optimal stomatal variation that regulates the relationship between water loss through transpiration and carbon uptake through assimilation in response to the environment (Cowan, 1977; Farquhar and Sharkey, 1982). More recently, modeling and measurements of mass and energy exchange at the canopy scale in boreal forests showed that cool air temperatures after soil thaw were conducive to rapid carbon uptake, but respiration increased above $17^{\circ} \mathrm{C}$, indicating that years with early springs and cool wet summers were associated with stronger annual net carbon uptake rates (e.g. BOREAS; Sellers et al., 1997a). Inter-comparisons of model results have also been conducted to investigate variation in simulations. Comparisons have been made on simulated sensible and latent heat fluxes amongst land-surface sub-models of general circulation models (Pitman and Henderson-Sellers, 1998; Pitman et al., 1999; Sellers et al., 1997b), and simulated net ecosystem production amongst dynamic global vegetation models (Cramer et al., 2001). With technological advancements and the establishment of an international network, FLUXNET (Baldocchi et al., 2001; Valentini et al., 2000; http://www.eosdis.ornl.gov/FLUXNET), we now have available a large body of data on terrestrial ecosystem exchange of mass and energy that is integrated at the stand level, with accompanying meteorological and biological measurements. This information can be used in combination with models to better understand temporal and spatial variation in fluxes.

The net ecosystem exchange (NEE) of $\mathrm{CO}_{2}$ between the biosphere and the atmosphere is the balance between fluxes associated with photosynthetic assimilation by the foliage (gross ecosystem production (GEP)) and respiratory effluxes from autotrophs $\left(R_{\mathrm{a}}\right)$ and heterotrophs $\left(R_{\mathrm{h}}\right)$. Differences in annual NEE between locations might be attributable to disturbance history, climate, nutrition, biome type, and physiological differences associated with age (Law et al., 2001a; 
Schulze et al., 1999, 2000). Environmental conditions may influence photosynthetic uptake and autotrophic and heterotrophic respiration differently. Research in European forests showed that there was no correlation between GEP and latitude, but annual ecosystem respiration increased with latitude, in spite of the decrease in mean annual temperature (Valentini et al., 2000). Other studies have shown that ecosystem respiration is primarily from soils (Janssens et al., 2001; Law et al., 1999a,b; Goulden et al., 1996b, 1998). Although strong correlations have been found between soil surface $\mathrm{CO}_{2}$ efflux and temperature within sites, a poor correlation was found between decomposition of organic carbon in mineral soil and mean annual temperature across sites (e.g., Giardina and Ryan, 2000). Studies have also identified relations between periodicities or amplitudes in climate and plant processes, as well as temporal variation in responses of different ecosystem processes to environmental variables (Bowling et al., 2002; Woodward, 1987).

Although the measurement of ecosystem fluxes is useful for understanding responses to the environment at individual sites, we cannot measure ecosystem fluxes everywhere and continuously over the long-term. If our flux site information is to be used for spatial and temporal integration, we need to produce canopy scale response functions that the models can use and test.

Results from bottom-up biomass inventories, inverse modeling studies that combine flask measurements of carbon dioxide $\left(\mathrm{CO}_{2}\right)$ with global circulation models, and terrestrial modeling activities suggest that $\mathrm{CO}_{2}$ fluxes strongly reflect the impacts of disturbance history, whereas inter-annual differences in carbon sources and sinks are likely to be driven primarily by the effect of climate on ecosystem processes (Schimel et al., 2000, 2002). Thus, a key issue for current and future research is to quantify the causal link between climate and $\mathrm{CO}_{2}$ exchange for all major terrestrial ecosystems as a basis for model prediction.

The objective of this research was to compare seasonal and annual estimates of $\mathrm{CO}_{2}$ and water vapor exchange across sites in forests, grasslands, crops and tundra, and to investigate the magnitude and variation in responses of vegetation to environmental variables, and the linkage between carbon uptake and water loss. The overall goal is to elucidate general responses within and between biomes and to provide informa- tion for modeling of carbon and water cycling across regions and around the globe. The intent is to provide insight into general response functions for modeling carbon and water processes for both regional and global climate models and identify the differences to show where land-surface models can be improved. This data set includes sites where temperature and precipitation co-vary seasonally (e.g. they increase together during summer months), and sites where they are decoupled (e.g. regions where drought occurs during the summer growing season), which allows us to determine if relations between processes and environmental variables are consistent for the pooled data.

\section{Methods}

This study represents a synthesis of data from flux sites in deciduous and evergreen forests, grasslands, crops, and tundra vegetation. The geographic range of the sites varies in latitude from $2^{\circ}$ to $65^{\circ} \mathrm{N}$ and in longitude from $20^{\circ} \mathrm{W}$ to $25^{\circ} \mathrm{E}$. The climatic zones include temperate continental, oceanic, Mediterranean, and boreal. Automated micrometeorological measurements were made of $\mathrm{CO}_{2}$ and water vapor exchange over vegetation at the sites, and ancillary data, such as soil properties, leaf area index (LAI), and net primary productivity (NPP) were collected. The experimental sites are monotypic biomes representative of regional vegetation. Table 1 shows the characteristics and codes for the sites.

We limited this study to a subset of sites where climate and flux data have been analyzed, following consistent methods, and archived (Falge et al., 2001; Baldocchi et al., 2001; Aubinet et al., 2000). Carbon, water vapor, and energy fluxes were estimated with the eddy covariance technique from towers above the vegetation canopies. Flux systems comprised three-axis sonic anemometers that measured wind speed and virtual temperature, infrared gas analyzers that measured concentrations of water vapor and $\mathrm{CO}_{2}$, and a suite of software for real-time and post-processing analysis. Fluxes were averaged half-hourly, and the records in the database were evaluated for data quality.

Although the intent is to obtain continuous NEE measurements, missing data occur because of system failure or data rejection. The average data coverage over the year was $65-75 \%$. For our study, we filled 
Table 1

Site characteristics, including growing season temperature $\left(T_{\text {grow }}\right)$, annual precipitation $(P)$, water balance $\left(\sum(\mathrm{ET}-P)\right)$, LAI, net ecosystem CO 2 exchange $(\mathrm{NEE})$, and ecosystem respiration $\left(R_{\mathrm{e}}\right)$ (missing values indicate there were not enough data through the year after data screening, see Section 2 )

\begin{tabular}{|c|c|c|c|c|c|c|c|c|c|c|c|c|}
\hline Site (symbol) & Location & $\begin{array}{l}\text { Elevation } \\
(\mathrm{m})\end{array}$ & Climate $^{\mathrm{a}}$ & $\begin{array}{l}T_{\text {grow }} \\
\left({ }^{\circ} \mathrm{C}\right)\end{array}$ & $\begin{array}{l}P \\
(\mathrm{~mm})\end{array}$ & $\sum(\mathrm{ET}-P)$ & $\mathrm{Age}^{\mathrm{b}}$ & $\begin{array}{l}\mathrm{LAI}^{\mathrm{C}} \\
\left(\mathrm{m}^{2} \mathrm{~m}^{-2}\right)\end{array}$ & $\begin{array}{l}\text { NEE }\left(\mathrm{g} \mathrm{Cm}^{-2}\right. \\
\text { per year })\end{array}$ & $\begin{array}{l}R_{\mathrm{e}}\left(\mathrm{g} \mathrm{Cm}^{-2}\right. \\
\text { per year) }\end{array}$ & Period & Citation \\
\hline \multicolumn{13}{|l|}{ Evergreen coniferous forests } \\
\hline \multirow[t]{2}{*}{ Aberfeldy, Scotland (AB) } & $56^{\circ} 37^{\prime} \mathrm{N}, 3^{\circ} 48^{\prime} \mathrm{W}$ & 340 & o & 8.9 & 958 & -991 & 14 & 8 & -707 & 1384 & 1997 & Valentini et al. (2000) \\
\hline & & & & 9.0 & 1242 & -887 & & & -487 & 1270 & 1998 & \\
\hline $\begin{array}{l}\text { Blodgett Forest, CA, } \\
\text { USA (BL) }\end{array}$ & $38^{\circ} 54^{\prime} \mathrm{N}, 120^{\circ} 38^{\prime} \mathrm{W}$ & 1315 & M & & 2210 & & $10(\mathrm{CC}, \mathrm{P} 1980)$ & $3.2(1997)$ & & & 1997 & $\begin{array}{l}\text { Law et al. }(2001 \mathrm{c}) \text {, } \\
\text { Xu et al. }(2001)\end{array}$ \\
\hline Bordeaux, France (BO) & $44^{\circ} 05^{\prime \prime} \mathrm{N}, 0^{\circ} 05^{\prime} \mathrm{E}$ & 60 & $\mathrm{o}$ & 17 & 995 & -313 & $30(C C$, P 1970) & $\begin{array}{l}4.5(1998) \\
2.8\end{array}$ & -525 & 1638 & 1997 & $\begin{array}{l}\text { Hassika and } \\
\text { Berbigier (1998) }\end{array}$ \\
\hline Duke, NC, USA (DU) & $36^{\circ} 2^{\prime} \mathrm{N}, 79^{\circ} 8^{\prime} \mathrm{W}$ & 163 & $\mathrm{~T}$ & $\begin{array}{l}17.2 \\
170\end{array}$ & 748 & -243 & 17 (CC, B, P 1983) & 5.2 & $\begin{array}{l}-538 \\
-651\end{array}$ & 941 & 1998 & This study \\
\hline \multirow[t]{2}{*}{ Flakaliden, Sweden (FL) } & $64^{\circ} 07^{\prime} \mathrm{N}, 19^{\circ} 27^{\prime} \mathrm{E}$ & 225 & B & 12.6 & 198 & 100 & 31 & 2 & -173 & $\begin{array}{l}049 \\
526 \\
720\end{array}$ & 1997 & Lindroth et al. (1998) \\
\hline & & & & 10.2 & 429 & -206 & & & 53 & 798 & 1998 & \\
\hline \multirow[t]{2}{*}{ Howland, ME, USA (HL) } & $45^{\circ} 12^{\prime} \mathrm{N}, 68^{\circ} 44^{\prime} \mathrm{W}$ & 60 & TC & 11.9 & 1045 & -692 & 90 & 5.5 & -246 & & 1996 & Hollinger et al. (1999) \\
\hline & & & & 13.8 & 710 & -350 & & & -256 & & 1997 & \\
\hline \multirow[t]{2}{*}{ Hyytiälä, Finland (HY) } & $61^{\circ} 51^{\prime} \mathrm{N}, 24^{\circ} 17^{\prime} \mathrm{E}$ & 170 & B & 13.3 & 540 & -223 & $35(1997)$ & 3 & -228 & 720 & 1997 & $\begin{array}{l}\text { Markkanen et al. (2001), } \\
\text { Vesala et al. (1998) }\end{array}$ \\
\hline & & & & 11.5 & 681 & -455 & & & -264 & 700 & 1998 & \\
\hline Saskatchewan, Canada (JP) & $53^{\circ} 55^{\prime} \mathrm{N}, 104^{\circ} 41^{\prime} \mathrm{W}$ & 580 & B & 15.8 & 403 & & $75-90$ & 2 & & & 1994 & Baldocchi et al. (1997) \\
\hline \multirow{2}{*}{ Loobos, Netherlands (LO) } & $52^{\circ} 10^{\prime} \mathrm{N}, 5^{\circ} 45^{\prime} \mathrm{E}$ & 25 & $\mathrm{~T}$ & 13.3 & 758 & -339 & 80 & & -323 & 1114 & 1997 & Valentini et al. $(2000)$ \\
\hline & & & & 13.2 & 1266 & -901 & & & -199 & 1154 & 1998 & \\
\hline \multirow[t]{2}{*}{ Metolius, OR, USA (ME) } & $44^{\circ} 30^{\prime} \mathrm{N}, 121^{\circ} 37^{\prime} \mathrm{W}$ & 915 & $\mathrm{~T}$ & 9.7 & 867 & -239 & 45250 & 2.1 & -287 & 885 & 1996 & $\begin{array}{l}\text { Law et al. }(1999 a, b) \text {, Law } \\
\text { et al. }(2000,2001 a)\end{array}$ \\
\hline & & & & 9.6 & 488 & -74 & & & -257 & 996 & 1997 & \\
\hline \multirow[t]{4}{*}{ Manitoba, Canada (NB) } & $55^{\circ} 54^{\prime} \mathrm{N}, 98^{\circ} 30^{\prime} \mathrm{W}$ & 259 & B & 12.4 & 375 & -123 & $53-155$ & 4.8 & 20 & 836 & 1995 & Goulden et al. (1998) \\
\hline & & & & 13.1 & 337 & -104 & & & -3 & 861 & 1996 & \\
\hline & & & & 13.5 & 372 & -126 & & & 5 & 820 & 1997 & \\
\hline & & & & 13.3 & 300 & 90 & & & -36 & 782 & 1998 & \\
\hline \multirow[t]{2}{*}{ Norunda, Sweden (NO) } & $60^{\circ} 05^{\prime} \mathrm{N}, 17^{\circ} 28^{\prime} \mathrm{E}$ & 45 & TB & 11.9 & 656 & -311 & 100 & 5 & -75 & & 1996 & Lindroth et al. (1998) \\
\hline & & & & 10.0 & 483 & -102 & & & 101 & & 1997 & \\
\hline Niwot Ridge, CO, USA (NR) & $40^{\circ} 02^{\prime} \mathrm{N}, 105^{\circ} 33^{\prime} \mathrm{W}$ & 3050 & TS & 9.7 & 680 & & 95 & $3.7-4.3^{\mathrm{d}}$ & & & 1999 & Monson et al. (2002) \\
\hline \multirow[t]{3}{*}{ Tharandt, Germany (TH) } & $50^{\circ} 58^{\prime} \mathrm{N}, 13^{\circ} 38^{\prime} \mathrm{E}$ & 380 & $\mathrm{TC}$ & 12.0 & 1412 & -914 & 140 & 6 & & & 1997 & Valentini et al. (2000) \\
\hline & & & & 11.5 & 990 & -482 & & & & & 1998 & \\
\hline & & & & 12.6 & 951 & -411 & & & & & 1999 & \\
\hline $\begin{array}{l}\text { Weiden Brunnen, Germany } \\
\text { (WE) }\end{array}$ & $50^{\circ} 09^{\prime} \mathrm{N}, 11^{\circ} 52^{\prime} \mathrm{E}$ & 780 & SM & 11.7 & 1304 & -1071 & 40 & 5 & 24 & 1325 & 1998 & Valentini et al. (2000) \\
\hline Wind River, WA, USA (WR) & $45^{\circ} 49^{\prime} \mathrm{N}, 121^{\circ} 57^{\prime} \mathrm{W}$ & 355 & o & 9.5 & 2528 & & $400-500$ & 11 & -446 & & 1999 & Chen et al. (2002) \\
\hline \multicolumn{13}{|c|}{ Mixed evergreen and deciduous forests } \\
\hline \multirow{2}{*}{ Braschaat, Belgium (BR) } & $51^{\circ} 18^{\prime} \mathrm{N}, 4^{\circ} 31^{\prime} \mathrm{E}$ & 10 & $\mathrm{TC}$ & 17.5 & 662 & & 67 & 3 & 76 & 1033 & 1997 & Janssens et al. (2001) \\
\hline & & & & 17.0 & 1042 & -676 & & & 105 & 1218 & 1998 & \\
\hline \multirow[t]{3}{*}{ Park Falls, WI, USA (WL) } & $45^{\circ} 56^{\prime} \mathrm{N}, 90^{\circ} 16^{\prime} \mathrm{W}$ & $470-500$ & $\mathrm{TC}$ & 17.1 & 1092 & -714 & $60-80$ & 4 & -34 & 865 & 1997 & $\begin{array}{l}\text { Berger et al. (2001); } \\
\text { K. Davis, pers. commun. }\end{array}$ \\
\hline & & & & 15.1 & 525 & -118 & & & 55 & 1081 & 1998 & \\
\hline & & & & 18.1 & 706 & -312 & & & 44 & 829 & 1999 & \\
\hline \multicolumn{13}{|l|}{ Deciduous broadleaf forests } \\
\hline Gunnarsholt, Iceland (GU) & $63^{\circ} 50^{\prime} \mathrm{N}, 20^{\circ} 13^{\prime} \mathrm{W}$ & 78 & $\mathrm{o}$ & $\begin{array}{r}9.5 \\
10.9\end{array}$ & 1168 & & 5 & 1.4 & & & $\begin{array}{l}1997 \\
1998\end{array}$ & Valentini et al. (2000) \\
\hline \multirow[t]{3}{*}{ Hesse, France (HE) } & $48^{\circ} 40^{\prime} \mathrm{N}, 7^{\circ} 05^{\prime} \mathrm{E}$ & 300 & TC & 13.7 & 924 & -589 & 30 & 6 & -145 & 1009 & 1997 & $\begin{array}{l}\text { Valentini et al. (2000), } \\
\text { Granier et al. (2000a) }\end{array}$ \\
\hline & & & & 16.6 & 974 & -633 & & & 63 & 1429 & 1998 & \\
\hline & & & & 16.3 & 1096 & -687 & & & -182 & 1296 & 1999 & \\
\hline $\begin{array}{l}\text { Harvard Forest, MA, } \\
\text { USA (HV) }\end{array}$ & $42^{\circ} 32^{\prime} \mathrm{N}, 72^{\circ} 11^{\prime} \mathrm{W}$ & $180-490$ & $\mathrm{~T}$ & 17.4 & 970 & -554 & 90 & 5.5 & -195 & 792 & 1992 & $\begin{array}{l}\text { Goulden et al. (1996a); } \\
\text { this study }\end{array}$ \\
\hline
\end{tabular}




\begin{tabular}{|c|c|c|c|c|c|c|c|c|c|c|c|c|}
\hline & & & & 16.6 & 1157 & -656 & & & -193 & 1003 & 1993 & \\
\hline & & & & 17.7 & 968 & -527 & & & -150 & 957 & 1994 & \\
\hline & & & & 18.4 & 938 & -457 & & & -242 & 875 & 1995 & \\
\hline & & & & 17.2 & 1379 & -942 & & & -148 & $937 x$ & 1996 & \\
\hline & & & & 16.0 & 908 & -463 & & & -234 & 942 & 1997 & \\
\hline & & & & 17.9 & 954 & -524 & & & -87 & 981 & 1998 & \\
\hline & & & & 19.0 & 1011 & -516 & & & -197 & 1043 & 1999 & \\
\hline \multirow[t]{3}{*}{ Soroe, Denmark (SO) } & $55^{\circ} 29^{\prime} \mathrm{N}, 11^{\circ} 39^{\prime} \mathrm{E}$ & 40 & то & 15.5 & 527 & -267 & 78 & 4.8 & -55 & 1131 & 1997 & Pilegaard et al. (2001) \\
\hline & & & & 13.7 & 791 & -525 & & & -48 & 1347 & 1998 & \\
\hline & & & & 14.6 & 1705 & -1455 & & & -88 & 1237 & 1999 & \\
\hline Vielsalm, Belgium (VB) & $50^{\circ} 18^{\prime} \mathrm{N}, 6^{\circ} 0^{\prime} \mathrm{E}$ & 450 & $\mathrm{~T}$ & 11.1 & 1261 & -1012 & $60-90$ & 4.5 & -507 & & 1998 & Valentini et al. (2000) \\
\hline \multirow[t]{4}{*}{$\begin{array}{l}\text { Walker Branch, TN, } \\
\text { USA (WB) }\end{array}$} & $35^{\circ} 57^{\prime} \mathrm{N}, 84^{\circ} 17^{\prime} \mathrm{W}$ & $365-380$ & $\mathrm{~T}$ & 19.6 & 1253 & -716 & 58 & 6.0 & -470 & 1038 & 1995 & $\begin{array}{l}\text { Wilson and Baldocchi }(2000 \mathrm{a}) \text {, } \\
\text { Wilson et al. (2000b), } \\
\text { Wilson et al. }(2001)\end{array}$ \\
\hline & & & & 21.2 & 1705 & -1151 & & & -576 & 1031 & 1996 & \\
\hline & & & & 20.2 & 1450 & -839 & & & -618 & 1037 & 1997 & \\
\hline & & & & 22.2 & 1663 & -1103 & & & -870 & 1052 & 1998 & \\
\hline Willow Creek, WI, USA (WC) & $45^{\circ} 47^{\prime} \mathrm{N}, 90^{\circ} 3^{\prime} \mathrm{W}$ & 480 & $\mathrm{TC}$ & 19.2 & 694 & -103 & $35-70$ & 4.2 & -180 & 769 & 1999 & B.D. Cook, pers. commun. \\
\hline \multicolumn{13}{|l|}{ Evergreen broadleaf forests } \\
\hline Castelporziano, Italy (CP) & $41^{\circ} 45^{\prime} \mathrm{N}, 12^{\circ} 22^{\prime} \mathrm{E}$ & 3 & M & $\begin{array}{l}14.9 \\
15.5\end{array}$ & 249 & & 50 & 3.5 & $\begin{array}{l}-518 \\
-653\end{array}$ & 1165 & $\begin{array}{l}1997 \\
1998\end{array}$ & Valentini et al. (2000) \\
\hline $\begin{array}{l}\text { Sky Oaks, CA, USA (Sky: } \\
\text { young, Sko: old) }\end{array}$ & $33^{\circ} 22^{\prime} \mathrm{N}, 116^{\circ} 37^{\prime} \mathrm{W}$ & 1420 & M & 17.1 & & & 10 (Sky) & 3 (Sko) & & 240 (Sky) & 1999 & This study \\
\hline \multicolumn{13}{|l|}{ Grasslands } \\
\hline \multirow[t]{2}{*}{ Little Washita, OK, USA (LW) } & $34^{\circ} 58^{\prime} \mathrm{N}, 97^{\circ} 59^{\prime} \mathrm{W}$ & & $\mathrm{TC}$ & 21.6 & 938 & -463 & & & 109 & & 1997 & Meyers (2001) \\
\hline & & & & 23.3 & 715 & -314 & & & 422 & 552 & 1998 & \\
\hline Shidler, OK, USA (SH) & $36^{\circ} 51^{\prime} \mathrm{N}, 96^{\circ} 41^{\prime} \mathrm{W}$ & & $\mathrm{TC}$ & 23.2 & 1112 & -504 & & $0.0-2.9$ & -362 & 1354 & 1997 & This study \\
\hline \multicolumn{13}{|l|}{ Tundra } \\
\hline Atqasuk, AK, USA (AT) & $70^{\circ} 29^{\prime} \mathrm{N}, 157^{\circ} 25^{\prime} \mathrm{W}$ & 1 & $\mathrm{TU}$ & & & & & & & & 1999 & Oechel et al. (2000) \\
\hline Barrow, AK, USA (BA) & $70^{\circ} 18^{\prime} \mathrm{N}, 156^{\circ} 38^{\prime} \mathrm{W}$ & 1 & $\mathrm{TU}$ & & 36 (June-August) & & $\begin{array}{l}\text { Mature tussock } \\
\text { tundra, wet sedge } \\
8000-10000\end{array}$ & $1.0-1.5$ & & & $\begin{array}{l}1998 \\
1999\end{array}$ & Oechel et al. (2000) \\
\hline Happy Valley, AK, USA (HP) & $69^{\circ} 08^{\prime} \mathrm{N}, 148^{\circ} 50^{\prime} \mathrm{W}$ & 366 & $\mathrm{TU}$ & & & & $8000-10000$ & $1.0-1.5$ & & & $\begin{array}{l}1994 \\
1995\end{array}$ & Oechel et al. (2000) \\
\hline Upad, AK, USA (UP) & $70^{\circ} 16^{\prime} \mathrm{N}, 148^{\circ} 53^{\prime} \mathrm{W}$ & 3 & $\mathrm{TU}$ & & & & $8000-10000$ & $1.0-1.5$ & & & 1994 & Oechel et al. (2000) \\
\hline \multicolumn{13}{|l|}{ Crops } \\
\hline \multirow[t]{3}{*}{ Bondville, IL, USA (BV) } & $40^{\circ} \mathrm{N}, 88^{\circ} 18^{\prime} \mathrm{W}$ & 213 & $\mathrm{TC}$ & 22.6 & 709 & -168 & $\begin{array}{l}\mathrm{C}_{4}, \mathrm{C}_{3} \text {; annual } \\
\text { rotation corn, } \\
\text { soybeans }\end{array}$ & $0-3.8$ & -543 & 894 & 1997 & Meyers (2001) \\
\hline & & & & 22.7 & 930 & -283 & & & 133 & 713 & 1998 & \\
\hline & & & & 23.1 & 813 & -193 & & & -634 & 945 & 1999 & \\
\hline Ponca City, OK, USA (PO) & $36^{\circ} 45^{\prime} \mathrm{N}, 97^{\circ} 05^{\prime} \mathrm{W}$ & & $\mathrm{TC}$ & 21.4 & 1184 & -327 & $C_{3}$ winter wheat & $0-5$ & -155 & 1240 & 1997 & This study \\
\hline
\end{tabular}


date gaps by means of standardized methods (look-up table method, Falge et al., 2001) to provide complete data sets. Average NEE was compiled for a maximum of 6 (or 4 ) seasonal periods $\times 23 Q_{\mathrm{PPFD}}$-classes $\times$ $35 T_{\mathrm{a}}$-classes. $Q$ PPFD-classes (photosynthetic photon flux density (PPFD)) consisted of $100 \mu \mathrm{mol} \mathrm{m}^{-2} \mathrm{~s}^{-1}$ intervals, ranging from 0 to $2200 \mu \mathrm{mol} \mathrm{m}^{-2} \mathrm{~s}^{-1}$, with a separate class for $Q_{\text {PPFD }}=0$. Similarly, $T_{\mathrm{a}}$-classes (air temperature) were defined as $2{ }^{\circ} \mathrm{C}$ intervals ranging from -19 to $49^{\circ} \mathrm{C}$. The procedure produced tables of NEE means and standard deviations for each class. Gaps in the look-up tables were interpolated linearly. To allow fast access to multiple records, the data are stored in a unified format, available in daily, weekly, monthly, and annual time resolution for a variety of potential uses.

Ecosystem respiration $\left(R_{\mathrm{e}}\right)$ was calculated for each half-hour from site-specific relationships between nocturnal NEE and soil temperature, and summed into weekly and monthly values. For further details on $R_{\mathrm{e}}$ calculations, see Falge et al. (2002). Briefly, $R_{\mathrm{e}}$ was derived from exponential regressions between nighttime fluxes at high friction velocity and soil temperature. An Arrhenius equation (Eq. (1)) from Lloyd and Taylor (1994) was used with a reference temperature $\left(T_{\text {ref }}\right)$ of $283.16 \mathrm{~K} . R_{\mathrm{e}, T_{\text {ref }}}$ and $E_{\mathrm{a}}$ are the fitted parameters. $R_{\mathrm{e}}, T_{\mathrm{ref}}$ is the ecosystem respiration rate at $T_{\text {ref }} ; E_{\mathrm{a}}$ is the activation energy in $\mathrm{J} \mathrm{mol}^{-1} ; R$ is the gas constant $\left(8.134 \mathrm{~J} \mathrm{~K}^{-1} \mathrm{~mol}^{-1}\right) ; T_{\mathrm{K}}$ is the soil temperature at $5 \mathrm{~cm}$ depth:

$R_{\mathrm{e}, \text { night }}=R_{\mathrm{e}, T_{\text {ref }}} \mathrm{e}^{\left(E_{\mathrm{a}} / R\left(\left(1 / T_{\mathrm{ref}}\right)-\left(1 / T_{\mathrm{K}}\right)\right)\right)}$

A single value of $E_{\mathrm{a}}$ was calculated for each site over the entire year. The parameter $R_{\mathrm{e}, T_{\text {ref }}}$ was evaluated for a 30-day moving window starting from January 1. The derived parameter sets were applied over the entire year and the half-hourly results were summed into daily values.

GEP represents the net rate of carboxylation and oxygenation by the enzyme ribulose bisphosphate carboxylase/oxygenase (RUBISCO), which constitutes about half of the soluble protein in leaves in $\mathrm{C}_{3}$ plants, and can interact with $\mathrm{CO}_{2}$, leading to photosynthesis (Nobel, 1991). GEP does not include photorespiration, so it is not equivalent to leaf chamber measurements of net assimilation. GEP was calculated from the difference between daytime NEE and daytime $R_{\mathrm{e}}$, where a net gain of carbon by the ecosystem is negative in the convention of micrometeorological measurements and $R_{\mathrm{e}}$ is positive. We compared weekly, monthly, and annual estimates of NEE, GEP, and ET, and investigated responses to environmental variables. Data were removed from the analyses if more than $25 \%$ of the data for the year was missing, and more than $65 \%$ of the data for the month. Because we applied a consistent approach of data analysis and screening, annual estimates in Table 1 may differ slightly from previously published data for individual sites. Some vegetation types or sites do not appear in some analyses because of limited data (e.g., annual GEP and water balance for evergreen broadleaf and tundra vegetation).

Uncertainty estimates have been discussed in detail in Moncrieff et al. (1996) and in papers from individual sites (e.g., Anthoni et al., 1999; Goulden et al., 1996b; Grelle, 1997). Systematic errors include uncertainties in gas analyzer calibrations related to calibration gases $(\sim \pm 3 \%)$ and changes in analyzer calibration because of residue on the analyzer optics (e.g., $\sim \pm 5-10 \%)$. Instabilities in calibration coefficients from diurnal changes in temperature and pressure are often assumed to be $<5 \%$. Uncertainties in wind speed and virtual temperature measured by the sonic anemometers are estimated to result in $\sim \pm 2 \%$ uncertainty in the scalar fluxes (Grelle, 1997). These systematic errors amount to $\sim \pm 12 \%$ of the daytime $\mathrm{CO}_{2}$ fluxes (Anthoni et al., 1999). Systematic micrometeorological problems might be much more substantial for certain sites. These potential problems include missing low frequency fluxes, spectral degradation caused by closed-cell instruments, horizontal and vertical advection (Massman and Lee, 2002; Eugster and Siegrist, 2000), and lack of energy balance closure and uncertainty of its importance to $\mathrm{CO}_{2}$ fluxes.

Janssens et al. (2001) suggested that total $R_{\mathrm{e}}(24 \mathrm{~h})$ can be overestimated by as much as $15 \%$ if nocturnal data are used, because of daytime inhibition of leaf respiration (Brooks and Farquhar, 1985). Comparisons of nocturnal eddy covariance fluxes and scaled-up chamber estimates of $R_{\mathrm{e}}$ have indicated that underestimation due to advective losses might be as high as 30\% of $R_{\mathrm{e}}$ at some sites on calm nights (Law et al., 1999a; Lavigne et al., 1997; Goulden et al., 1996b). This bias in this study was minimized because we used only flux data from periods of high friction velocity $(u *)$. We used site-specific thresholds of $u *$, above which the parameters of an exponential regression between 
nighttime NEE and soil temperature did not change anymore. At a few sites in complex terrain, or where low wind conditions prevailed at night, we calculated $R_{\mathrm{e}}$ and nocturnal NEE from alternative methods. We used scaled-up chamber estimates for nocturnal fluxes at ME (see Table 1; Law et al., 2000). For WB (see Table 1), we parameterized the CANOAK model with seasonal chamber measurements on soils, stems, and foliage and replaced nocturnal eddy covariance measurements with modeled nocturnal $\operatorname{NEE}\left(R_{\mathrm{e}}\right)$, following model validation with daytime fluxes (Wilson et al., 2000b). We measured diffuse and direct incident PPFD at a subset of sites and used the data to evaluate the association between NEE and light quality.

The start and end dates of the growing season were identified by the week that was the first of two or more consecutive weeks with negative NEE (net carbon uptake; Falge et al., 2002). We used mean daily air temperature to calculate the mean growing season temperature for this period. We calculated site water balance from the difference between daily ET and daily precipitation $\left(P_{\text {daily }}\right)$, summed weekly, monthly, and yearly:

$\sum\left(\mathrm{ET}_{\text {daily }}-P_{\text {daily }}\right)$

This is a reasonable estimate of water balance, which has been used in the past (e.g., Budyko, 1984). Runoff components were ignored in this application. Another method is to add soil water storage to precipitation (e.g., Running and Coughlan, 1988), but not all sites have continuous soil moisture measurements. Eq. (2) includes rain interception as evaporation $(15-25 \%$ of rainfall, with greater interception in more dense canopies) and evaporation from soil surfaces, but it could underestimate the intensity of water stress.

\section{Results and discussion}

\subsection{Light quality}

For a subset of sites, we separated radiation data into clear and cloudy sky conditions using two criteria. First, a clearness index (the ratio of global solar irradiance at the surface to extraterrestrial solar irradiance) must increase smoothly with solar elevation angle. Second, the curve of the relation between the clearness index and solar elevation angle must form a boundary line. The remaining data were considered to be cloudy sky conditions.

The highest solar irradiance for a given solar elevation angle occurs on partly cloudy days, not on clear days. This is due to a phenomenon termed 'cumulus solar irradiance reflection' by Segal and Davis, 1992 or 'cloud gap effect' described in Gu et al. (1999, 2001a). On cloudy days, sunlit ground surfaces are located at the end of solar beam paths through gaps formed by individual clouds in the vicinity. These areas receive the same amount of direct radiation as under clear sky conditions, but the incident diffuse radiation is increased due to light scattering and reflection from clouds in the vicinity (Oke, 1978). There can be as many bright cloudy periods as there are bright sunny periods during the growing season (e.g. when moisture is not limiting, and connective cumulus cloud formation dominates), as evident in a frequency analysis in a tropical forest (Gu et al., 2001b).

Cloud-cover results in a greater proportion of diffuse radiation and constitutes a higher fraction of light penetrating to lower depths of the canopy (Oechel and Lawrence, 1985). Goulden et al. (1997), Fitzjarrald et al. (1995), and Sakai et al. (1996) showed that net carbon uptake was consistently higher during cloudy periods in a boreal coniferous forest than during sunny periods with the same PPFD. Hollinger et al. (1994) found that daily net $\mathrm{CO}_{2}$ uptake was greater on cloudy days, even though total PPFD was 21-45\% lower on cloudy days than on clear days.

For a given solar elevation angle, decreases in total PPFD indicate changes in sky conditions from clear to cloudy, along with an increase in diffuse radiation, whereas air and soil temperature and vapor pressure deficit (VPD) tend to decrease (Gu et al., 1999). Ecosystem respiration decreases with air and soil temperatures, when water is not limiting, and leads to more net carbon uptake (more negative NEE) for a constant level of gross photosynthesis. For the same PPFD and temperature, respiration may be reduced under clear sky compared with cloudy conditions, perhaps because more soil moisture is available under cloudy conditions, and this may lead to higher soil respiration during early morning or late afternoon. Stomatal conductance $\left(g_{\mathrm{s}}\right)$ is a function of available water and evaporative demand, so that $g_{\mathrm{s}}$ tends to be higher at low VPDs, allowing more photosynthetic 

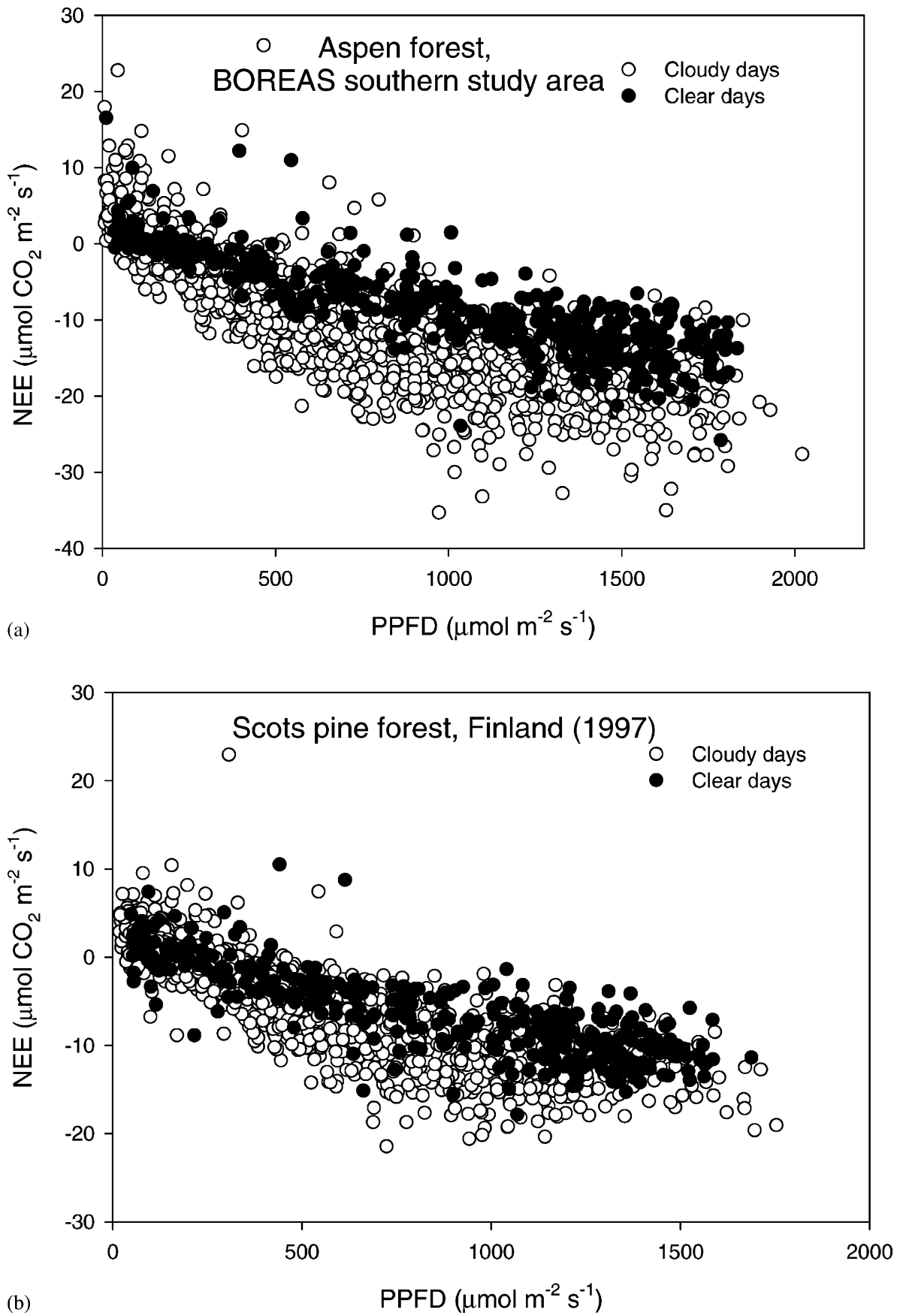

Fig. 1. NEE of $\mathrm{CO}_{2}$ in relation to diffuse and direct PPFD for (a) a boreal aspen forest, and (b) a boreal coniferous forest. Net carbon uptake was greater under diffuse sky conditions. (c) Gross photosynthesis in relation to PPFD for sunlit and shaded leaves, modeled with CANVEG. 


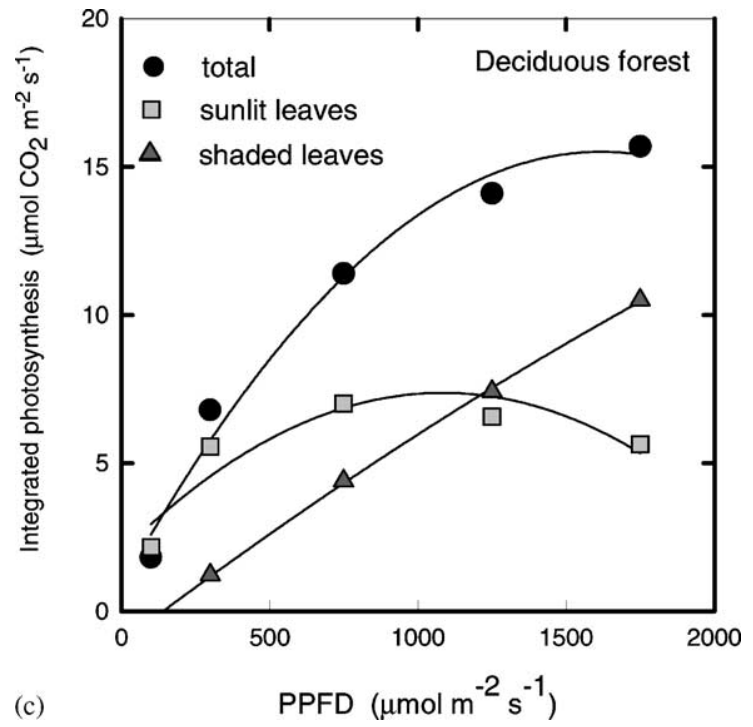

Fig. 1. (Continued).

carbon uptake. Therefore, when we plot NEE against total PPFD, based on solar elevation angles, we might not observe relationships similar to leaf response curves, which saturate at high levels of light.

Because photosynthetic efficiency is greater with diffuse radiation, it is important to evaluate NEE in relation to diffuse versus direct PPFD (Gu et al., 2001a). We found that NEE is more positive (less net carbon uptake) for clear sky than for cloudy conditions in boreal aspen and Scots pine forests (Fig. 1a and b). Simulations with the CANVEG model (Wilson et al., 2000b; Law et al., 2001b) demonstrate that photosynthesis is a linear function of PPFD for shade leaves and a curvilinear function of PPFD for sunlit leaves in a deciduous forest (Fig. 1c). Most process oriented models now distinguish sunlit and shade leaves; however, field data on diffuse and direct PPFD are sparse for model input (let alone total PPFD data) and often have to be modeled based on direct PPFD estimates and daily difference in minimum and maximum temperature (e.g., Thornton and Running, 1999).

\subsection{Temperature}

Respiration by soil autotrophs and heterotrophs can account for up to $75 \%$ of ecosystem respiration (Law et al., 2001a; Goulden et al., 1996b; Lavigne et al.,
1997; Janssens et al., 2001). At individual sites, respiration is correlated with temperature in the short-term, when water availability is not limiting soil processes (Law et al., 2001d; Lavigne et al., 1997; Lloyd and Taylor, 1994). On a monthly basis, the relationships between $R_{\mathrm{e}}$ and $T_{\mathrm{av}}$ (Fig. 2a and b) were good, but this result is confounded by the use of half-hourly air temperature and nocturnal NEE to estimate $R_{\mathrm{e}}$. The exponential coefficient for the relation between monthly $R_{\mathrm{e}}$ and $T_{\mathrm{av}}$ for the deciduous broadleaf forests $\left(R_{\mathrm{e}}=\right.$ $\left.46.4 \exp (0.056 x), r^{2}=0.61\right)$ corresponds to a $Q_{10}$ of 1.8 , close to the value of 2 that is typically used as a default in modeling respiration. The relationship between $R_{\mathrm{e}}$ and $T_{\mathrm{av}}$ was generally better for deciduous broadleaf forests (Fig. 2b) than for evergreen coniferous forests (Fig. 2a), which appear to have better correlations within site. The slopes of the relationship for individual evergreen coniferous sites were smaller for sites that were subject to drought during the growing season (e.g., BL and ME in Fig. 2a; see Table 1). The $R_{\mathrm{e}}$ for the boreal NO (see Table 1) site in Fig. 2a (vertical lines) was much higher than the $R_{\mathrm{e}}$ for the other coniferous sites, a result of previous soil drainage, which provided a large amount of accumulated substrate for heterotrophic respiration (Valentini et al., 2000). This result stresses the importance of knowing site history and the influence of recent site disturbance on decomposition rates. Boreal forests in northern latitudes typically have soil that is wetter for longer periods (Grace and Rayment, 2000). Respiration rates can be higher than those of terrestrial ecosystems at lower latitudes that experience periods of soil water deficits.

Monthly NEE was poorly correlated with $T_{\text {av }}$ and $\mathrm{T}_{\text {grow }}$, but respiration and photosynthesis, which contribute to NEE, probably respond to temperature differently. The relative controls of temperature and light on photosynthesis vary seasonally with changes in leaf area and biochemistry, and photosynthesis is limited at temperature extremes. Heterotrophic respiration can be limited by substrate quality and quantity, in addition to temperature and moisture, and this can have a large effect on total ecosystem respiration.

Although $R_{\mathrm{e}}$ correlates with temperature at a given site under moist conditions, we found a poor correlation between annual $R_{\mathrm{e}}$ and mean annual temperature $\left(T_{\text {av }}\right)$ across sites (linear and exponential temperature response $r^{2}=0.15,0.14$, respectively). The relation was poorer when we used growing season temperature 


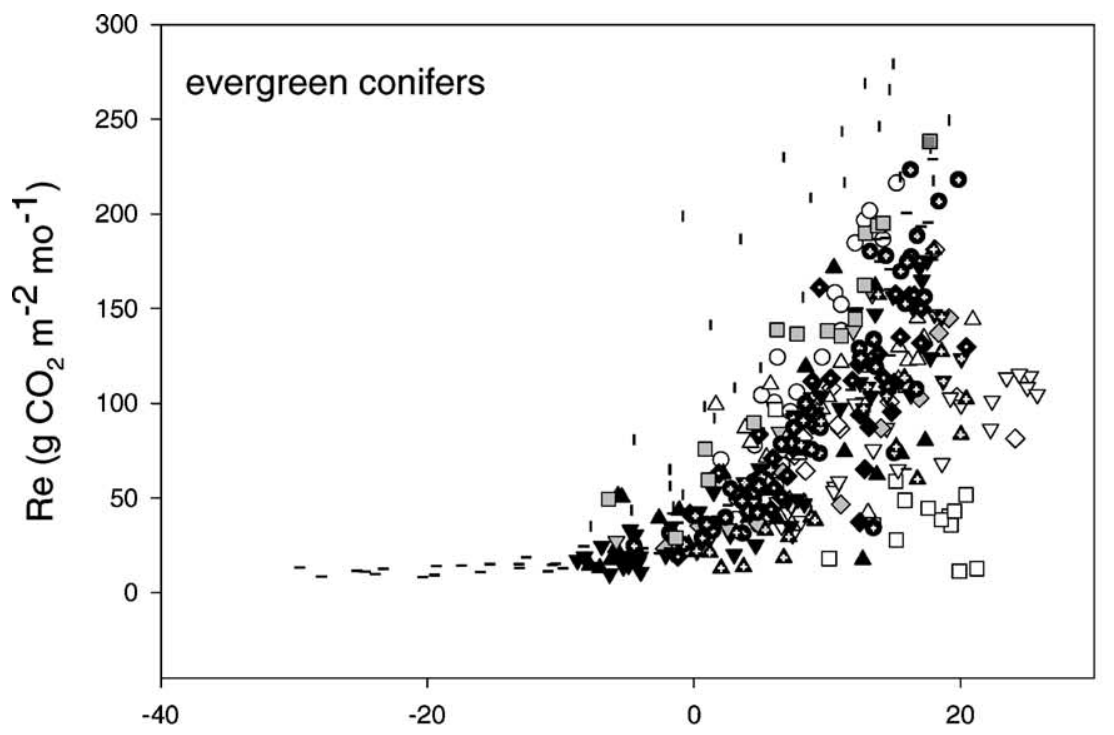

\begin{tabular}{|llll|}
\hline$\circ$ & AB97e & $\bullet$ & LO96e \\
0 & AB98e & $\bullet$ & LO97e \\
$\square$ & BL97 & $\bullet$ & LO98e \\
$\square$ & BL98 & $\nabla$ & ME96 \\
$\square$ & BL99 & $\nabla$ & ME97 \\
$\diamond$ & BO96e & - & NB94 \\
$\diamond$ & BO97e & - & NB95 \\
$\diamond$ & BO98e & - & NB96 \\
$\Delta$ & BR96e & - & NB97 \\
$\Delta$ & BR97e & - & NB98 \\
$\Delta$ & BR98e & 1 & NO96e \\
$\nabla$ & DU98 & 1 & NO97e \\
$\nabla$ & DU99 & 1 & NO98e \\
$\Delta$ & FL96e & $\nabla$ & NR99 \\
$\Delta$ & FL97e & $\bullet$ & TH96e \\
$\Delta$ & FL98e & $\bullet$ & TH97e \\
$\diamond$ & HL96 & $\bullet$ & TH98e \\
$\nabla$ & HY96e & $\bullet$ & TH99e \\
$\nabla$ & HY97e & $\square$ & WE96e \\
$\nabla$ & HY98e & $\square$ & WE97e \\
$\nabla$ & HY99e & $\mathbf{\Delta}$ & WR98 \\
$\bullet$ & JP94 & $\mathbf{\Delta}$ & WR99 \\
\hline
\end{tabular}

(a) Mean monthly air temperature $\left(24 \mathrm{~h},{ }^{\circ} \mathrm{C}\right)$

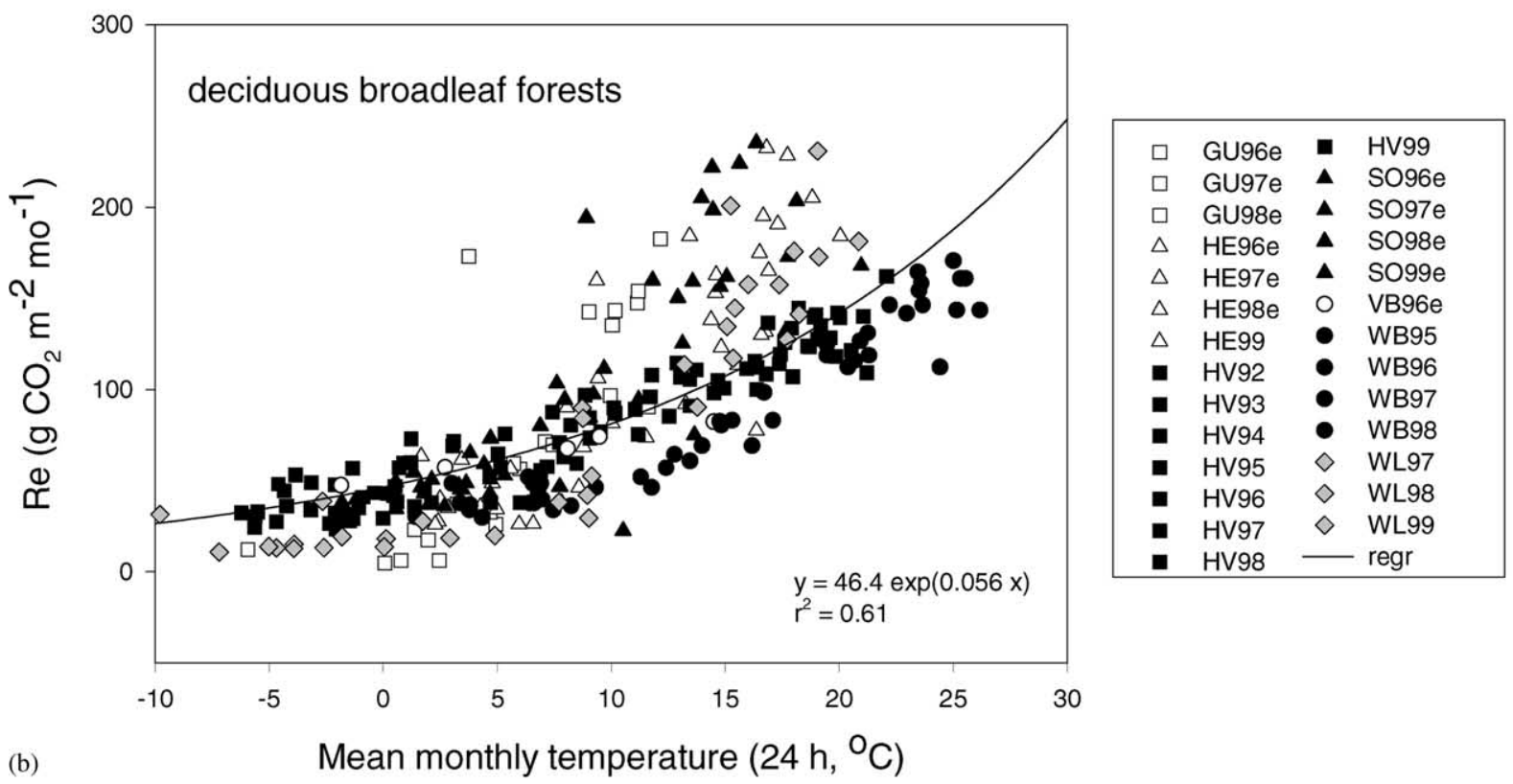

Fig. 2. Monthly cumulative ecosystem respiration increased with mean air temperature temperature at (a) evergreen coniferous forests and (b) deciduous broadleaf forests. Monthly GEP increased with temperature in evergreen coniferous forests.

$\left(T_{\text {grow }}\right)$. Computations have suggested that annual estimates of respiration for gross carbon budgets can be improved by including daily and seasonal temperature amplitudes (Ryan, 1991). Yet, over long periods of time (e.g., years to decades) across sites, heterotrophic decomposition might be influenced more by substrate quality and quantity (Giardina and Ryan, 2000; Liski et al., 1999). 
Table 2

Regression results for evergreen coniferous forests (EC), deciduous broadleaf forests (DB), grasslands (GR), crops (CR), and tundra (TU), where the equation is $y=a+b x$

\begin{tabular}{|c|c|c|c|c|c|}
\hline$Y$ variable & $X$ variable & Intercept, $a$ & Slope, $b$ & $r^{2}$ & SEE \\
\hline Annual GEP (EC, DB, GR) & $\sum(\mathrm{ET}-P)$ & 955 & -0.48 & 0.29 & 275 \\
\hline Annual GEP (all sites) & $T_{\mathrm{av}}$ & 852 & 47 & 0.50 & 246 \\
\hline Annual GEP (EC, DB, GR) & $T_{\mathrm{av}} \times \sum(\mathrm{ET}-P)$ & 943 & -0.06 & 0.64 & 188 \\
\hline Annual GEP & LAI & 838 & 92.2 & 0.12 & 291 \\
\hline LAI & $\sum(\mathrm{ET}-P)$ & 2.4 & -0.004 & 0.39 & 1.1 \\
\hline Annual NEE (all sites) & $\sum(\mathrm{ET}-P)$ & -70.8 & 0.24 & 0.12 & 225 \\
\hline Annual NEE (all sites) & $\overline{T_{\mathrm{av}}}$ & -60.7 & -21.5 & 0.17 & 240 \\
\hline Monthly GEP (all sites) & ET & 11.2 & 2.8 & 0.58 & 67 \\
\hline Monthly GEP (EC) & ET & 30.4 & 2.4 & 0.58 & 58 \\
\hline Monthly GEP (DB) & ET & -0.4 & 3.2 & 0.78 & 50 \\
\hline Monthly GEP (GR) & ET & -67.9 & 3.4 & 0.72 & 64 \\
\hline Monthly GEP (CR) & ET & -31.6 & 3.1 & 0.50 & 116 \\
\hline Monthly GEP (TU) & ET & 0.6 & 1.5 & 0.44 & 30 \\
\hline
\end{tabular}

Much of the dynamic response of processes to climate is lost in annual estimates, because of factors such as phenological influences. Annual NEE was poorly correlated with mean annual temperature $\left(r^{2}=0.17\right.$; Table 2). However, mean annual air temperature explained $50 \%$ of the variation in GEP across sites (Fig. 3). We caution that there could be autocorrelation in that GEP was calculated from the difference between daytime NEE and daytime $R_{\mathrm{e}}$, which was calculated from the relation between half-hourly nocturnal NEE and soil temperature. Valentini et al. (2000) showed that, for the EUROFLUX sites, annual

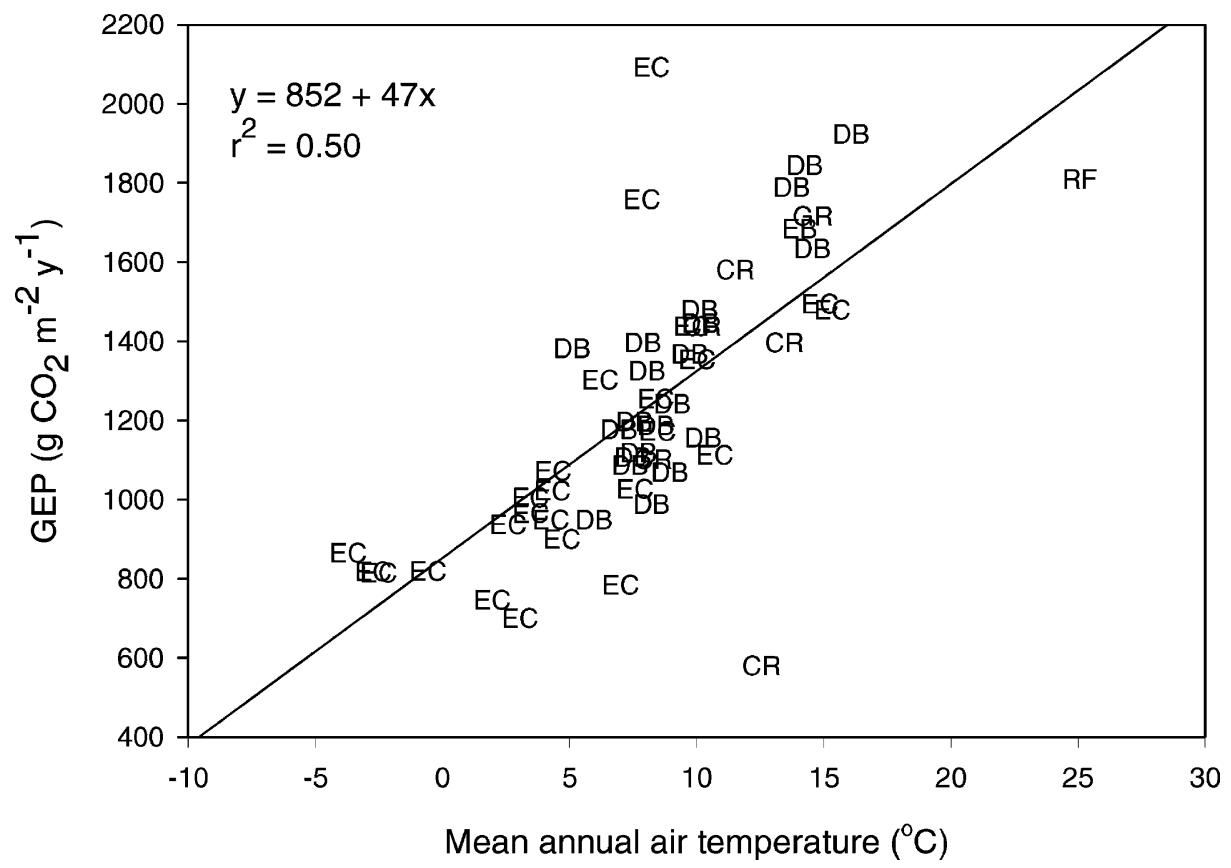

Fig. 3. Mean annual air temperature explained 50\% of the variation in GEP across biomes. Symbols are for evergreen coniferous forests (EC), deciduous broadleaf forests (DB), evergreen broadleaf forests (EB), and grasslands (GR). 
NEE decreased with latitude $\left(40^{\circ}-70^{\circ} \mathrm{N}\right)$, but there was no latitudinal trend in GEP. They suggested that ecosystem respiration was the main determinant of the relationship. In the EUROFLUX study, annual GEP ranged from $\sim 800$ to $1600 \mathrm{~g} \mathrm{C} \mathrm{m}^{-2}$ per year for sites that were not intensively managed. For a broader range of sites, Fig. 3 shows that annual GEP varied from $700 \mathrm{~g} \mathrm{C} \mathrm{m}^{-2}$ per year in a boreal forest (FL site; see Table 1) to $1800 \mathrm{~g} \mathrm{C} \mathrm{m}^{-2}$ per year in a tropical forest (MA site; see Table 1). GEP is the integrated photosynthetic response to climate, nutrients, and disturbance and can vary considerably within a small latitudinal range. For example, at $44^{\circ} \mathrm{N}$ latitude in the United States (OTTER project), there exist mild maritime, montane, and cold, semi-arid conditions across a $350 \mathrm{~km}$ east-west swath. As a result, forest NPP was five times greater for conifers in the mild maritime climate than for the semi-arid ponderosa pine and juniper sites (Law and Waring, 1994). Likewise, simulated GEP varied eightfold from $300 \mathrm{~g} \mathrm{C} \mathrm{m}^{-2}$ per year at the semi-arid sites to $2400 \mathrm{~g} \mathrm{C} \mathrm{m}^{-2}$ per year at the milder sites (Williams et al., 1997). Thus, we would not expect to see a latitudinal trend in GEP, because of the climatic variation within latitude and the effects of disturbance or forest management on LAI and GEP.

The relation between annual NEE and GEP is shown in Fig. 4. The slope of the relation was 0.44 for evergreen conifers and 0.67 for deciduous broadleaf forests (intercepts 285 and $618 \mathrm{~g} \mathrm{C} \mathrm{m}^{-2}$ per year, respectively). The ratio $R_{\mathrm{e}} / \mathrm{GEP}$ averaged 0.83 across all sites (range $0.55-1.2$ ), with values $>1$ (i.e., net loss of $\mathrm{CO}_{2}$ ) for boreal forests (NB; see Table 1) and

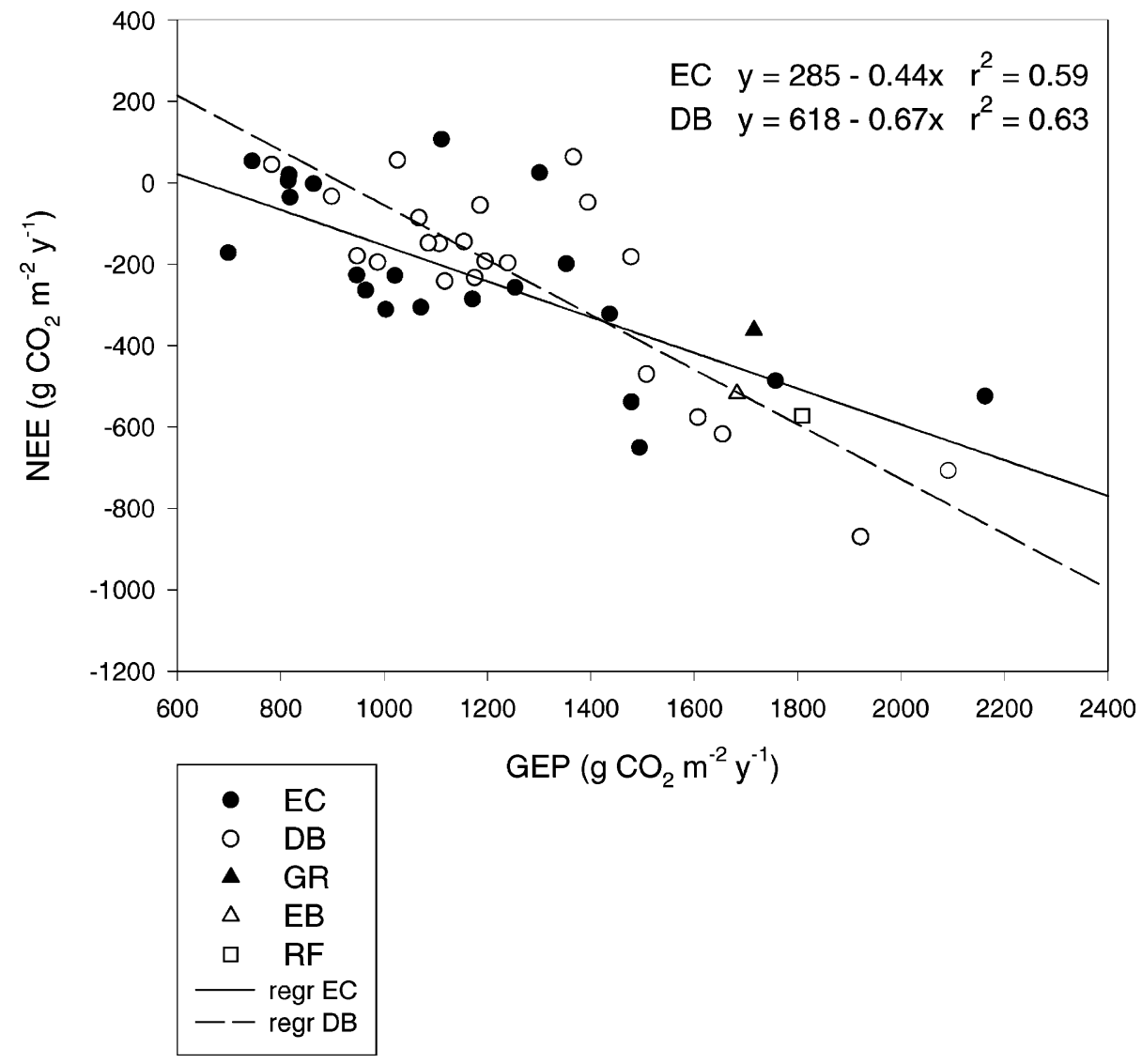

Fig. 4. The relation between annual NEP and GEP, where NEP $=-$ NEE. The regressions are shown for evergreen coniferous forests (EC) and deciduous broadleaf forests (DB). 
ecotonal temperate/boreal forests (WL and FL), as well as for northern temperate forests (BR, WE, and $\mathrm{HE}$ ), and a cropland (BV). The ratio includes shortand long-term effects on processes. In 1998, the BV crop of soybeans had high decomposition rates of residual left from the previous corn crop $\left(\mathrm{C}_{4}\right)$ under no-till agricultural practices. Excluding the BV site, the common feature of the sites with a ratio $>1$ is that these sites are generally cooler, with an average mean annual temperature of $4.7^{\circ} \mathrm{C}$, compared with the overall mean of $8.4^{\circ} \mathrm{C}$. The $R_{\mathrm{e}} / \mathrm{GEP}$ ratio was lowest for grasslands (mean 0.74 versus 0.82 for deciduous broadleaf forests and 0.85 for coniferous forests), presumably because of less investment in respiring plant tissue compared with forests. Because grasslands typically burn more frequently than other vegetation types, this ratio could be an underestimate of the loss of $\mathrm{CO}_{2}$ to the atmosphere over a longer time frame. It would be useful for carbon management purposes to evaluate carbon use efficiency or NEE over the long-term (e.g., several decades) to include such disturbance effects on carbon fluxes and storage.

\subsection{Water}

Water stress is the most common limitation to growth of vegetation (Kozlowski et al., 1991). The annual water balance (Eq. (2)) of most sites was negative, indicating more precipitation entering the sites than the amount of water lost through evaporation and transpiration. Remaining water was runoff or infiltration into the soil where it might have percolated to the water table. A caveat is that the micrometeorological instruments can lead to underestimates of ET under wet conditions because water droplets may form on the sonic anemometers and open path sensors. In addition, the energy balance lacks closure at most sites (see Wilson et al., 2002), which can result from underestimation of the components, including ET. A positive water balance was observed only at Flakaliden, Sweden (FL) and Manitoba, Canada (NB), both of which are boreal coniferous forests (Table 1). The NB soils are clay, organic, and some sandy deposits, derived predominantly from glacial deposits; FL has saturated peaty soil. The boreal coniferous forest in Finland (HY; see Table 1) did not show a positive annual water balance, possibly because soil in Finland (HY) is haplic podzol and till dominated by fine sand, which drains freely, a common feature of Finnish soil.

The annual site water balance explains $29 \%$ of the variation in annual GEP amongst forests and grasslands (Fig. 5a; Table 2). Earlier studies combined temperature and water balance $(T \times P / \mathrm{PET}$, where $T$ is the mean annual temperature, $P$ the annual precipitation, and PET (potential evapotranspiration) $=$ $0.18 \times$ growing season length $\times T_{\text {grow }}$ ) as an indicator of favorable growing conditions, and found a good correlation with the nutrient pool available to support photosynthesis (O'Neill and DeAngelis, 1981). We found a weak correlation between a similar index $\left(T_{\text {grow }} \times \sum(\mathrm{ET}-P)\right)$ and GEP $\left(r^{2}=0.33\right)$ amongst forests and grasslands. Using mean annual air temperature in the index $\left(T_{\mathrm{av}} \times \sum(\mathrm{ET}-P)\right)$ resulted in a good correlation with GEP $\left(r^{2}=0.64\right.$; Fig. $\left.5 b\right)$. The potential leaf area for a site is a long-term response to site water balance. For the sites with LAI data $(n=21)$, we found that annual water balance explained about $39 \%$ of the variation in LAI (Fig. 5c). The maximum LAI has been shown to correlate well with site water balance across a strong climatic gradient (Gholz, 1982; Grier and Running, 1977). In addition, environmental limitations to gross photosynthesis and carbon allocation influence the long-term potential leaf area, so there is somewhat of a correlation between site water balance, LAI, and GEP. On an annual basis, however, we found a poor correlation between GEP and LAI. Short-term variation in light quality, water availability, and VPDs can reduce photosynthesis below the potential of the leaf area present. In conifers, even though elongation of new needles may be limited during a drought year, the reduction in leaf area might not become apparent until the following year. Leaf longevity also plays a role-sites with the shortest needle longevity (e.g. 2 years) were in milder climates and had relatively high GEP. Finally, some of the water transpired could be deep soil water stored from previous years that is within reach of tree roots, leading to less water stress than might be expected under current climate conditions (Williams et al., 2001; Jones, 1992).

NEE and $R_{\mathrm{e}}$ were weakly correlated with site water balance, and the temperature-water balance index $\left(T_{\text {grow }} \times \sum(\mathrm{ET}-P) ; \mathrm{NEE} r^{2}=0.11\right)$, suggesting that respiration is controlled more strongly by other factors. Nevertheless, much of the inter-annual variability 

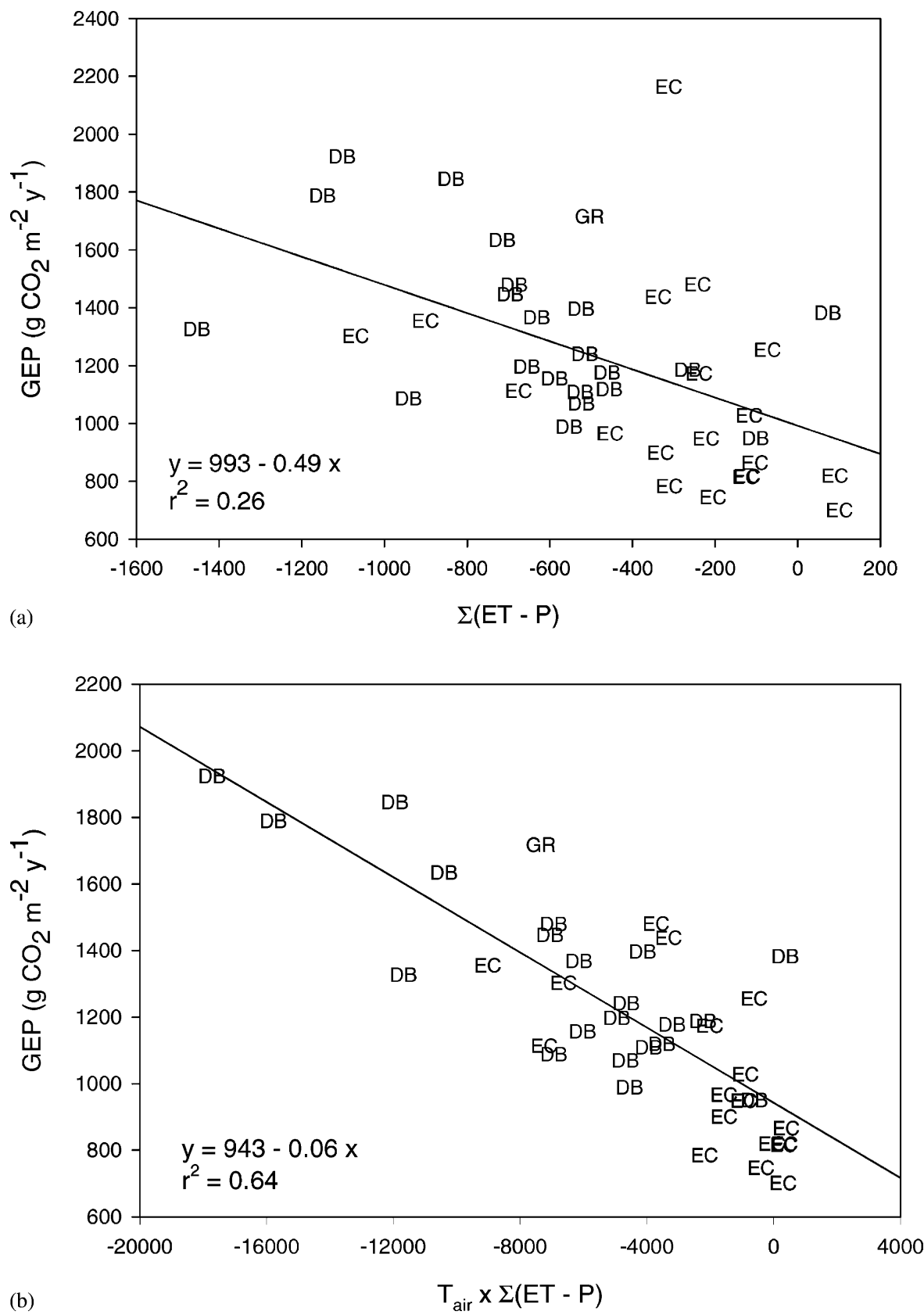

Fig. 5. (a) Annual site water balance, calculated from integrated ET minus precipitation ( $\sum(\mathrm{ET}-P)$, explains $29 \%$ of the variation in GEP across biomes. (b) The product of mean annual temperature and site water balance explains 53\% of the variation in annual GEP. (c) Annual site water balance explains $39 \%$ of the variation in LAI. Symbols are for evergreen coniferous forests (EC), deciduous broadleaf forests (DB), evergreen broadleaf forests (EB), and grasslands (GR). 


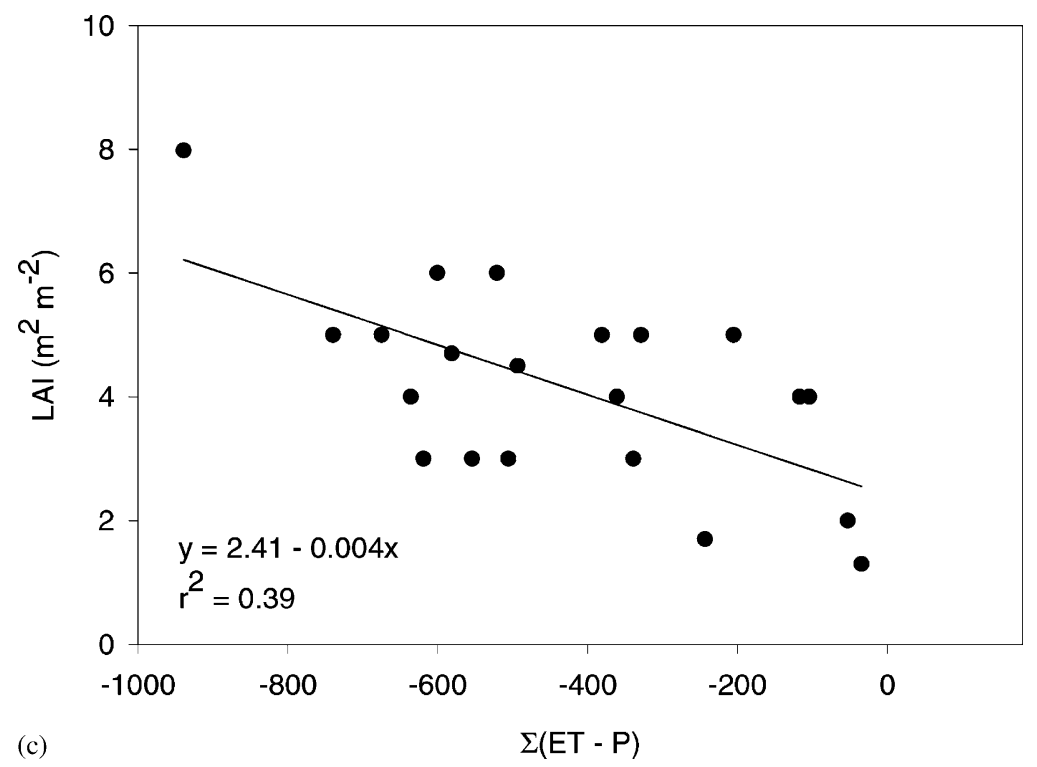

Fig. 5. (Continued).

in NEE at some evergreen (ME; see Table 1) and deciduous forests (HE; see Table 1) has been attributed to drought (Granier et al., 2000b; Law et al., 2000) because of water limitations to carbon uptake during the growing season and increased respiration with temperature.

Monthly GEP increased with ET across sites, with a strong correlation for deciduous broadleaf forests and the weakest correlation for tundra vegetation (Fig. 6a-d). The slope of the relationship indicates the amount of carbon taken up in photosynthesis relative to the amount of water lost by the ecosystem through evaporation and transpiration, integrated over the year. It can be considered an indicator of ecosystem water use efficiency (WUE). The slopes were similar between vegetation types (Fig. 6e), except for tundra vegetation (slopes $=3.4 \mathrm{~g} \mathrm{CO}_{2} / \mathrm{kg} \mathrm{H}_{2} \mathrm{O}$ for grasslands, 3.2 for deciduous broadleaf forests, 3.1 for crops, 2.4 for evergreen conifers, and 1.5 for tundra vegetation). Crops at the BV site (Fig. 6c; Table 1) are alternated annually between soybeans $\left(\mathrm{C}_{3}\right)$, and corn $\left(\mathrm{C}_{4}\right)$ and the slope for this site alone is $5.4\left(r^{2}=0.89\right)$. GEP is derived from eddy flux $R_{\mathrm{e}}$ and NEE, and $R_{\mathrm{e}}$ at the $\mathrm{BV}$ site includes a large amount of heterotrophic respiration from decomposing crop residuals, as mentioned earlier. The slope of the relation between GEP and ET was very low for the BL ponderosa pine plantation (Fig. 6a; Table 1) during a summer of extreme drought when cavitation was thought to have occurred, limiting carbon uptake (Law et al., 2001c). Excluding the BL site, the slope was 3.0 for evergreen conifers $\left(r^{2}=0.73\right)$. Within deciduous broadleaf forests, the amount of carbon uptake for a given amount of water vapor loss was greater for beech and poplar forests than for oak/maple forests, with the exception of WL (see Table 1), which includes conifers as well as poplars. Photosynthetic uptake was low in deciduous broadleaf forests, grasslands, crops, and tundra until ET exceeded $10-30 \mathrm{~kg} \mathrm{H}_{2} \mathrm{O} \mathrm{mol}^{-1}$, probably because evaporation occurred before photosynthetically active leaf area was present.

Kelliher et al. (1990) suggested that maximum ET was similar between the forest ecosystems they reviewed despite a fivefold range of LAI. They attributed this finding to plasticity in the partitioning of ET between the canopy and the understorey/soil surface, noting that: (1) additional units of LAI above a value of about 5 do not enhance canopy transpiration; (2) understorey and soil evapotranspiration tend to be inversely proportional to LAI. Several studies support this postulate (Black and Kelliher, 1989; Law et al., 2001b; Lafleur et al., 1993; Baldocchi et al., 1997). Sapflow measurements scaled to stands demonstrated 

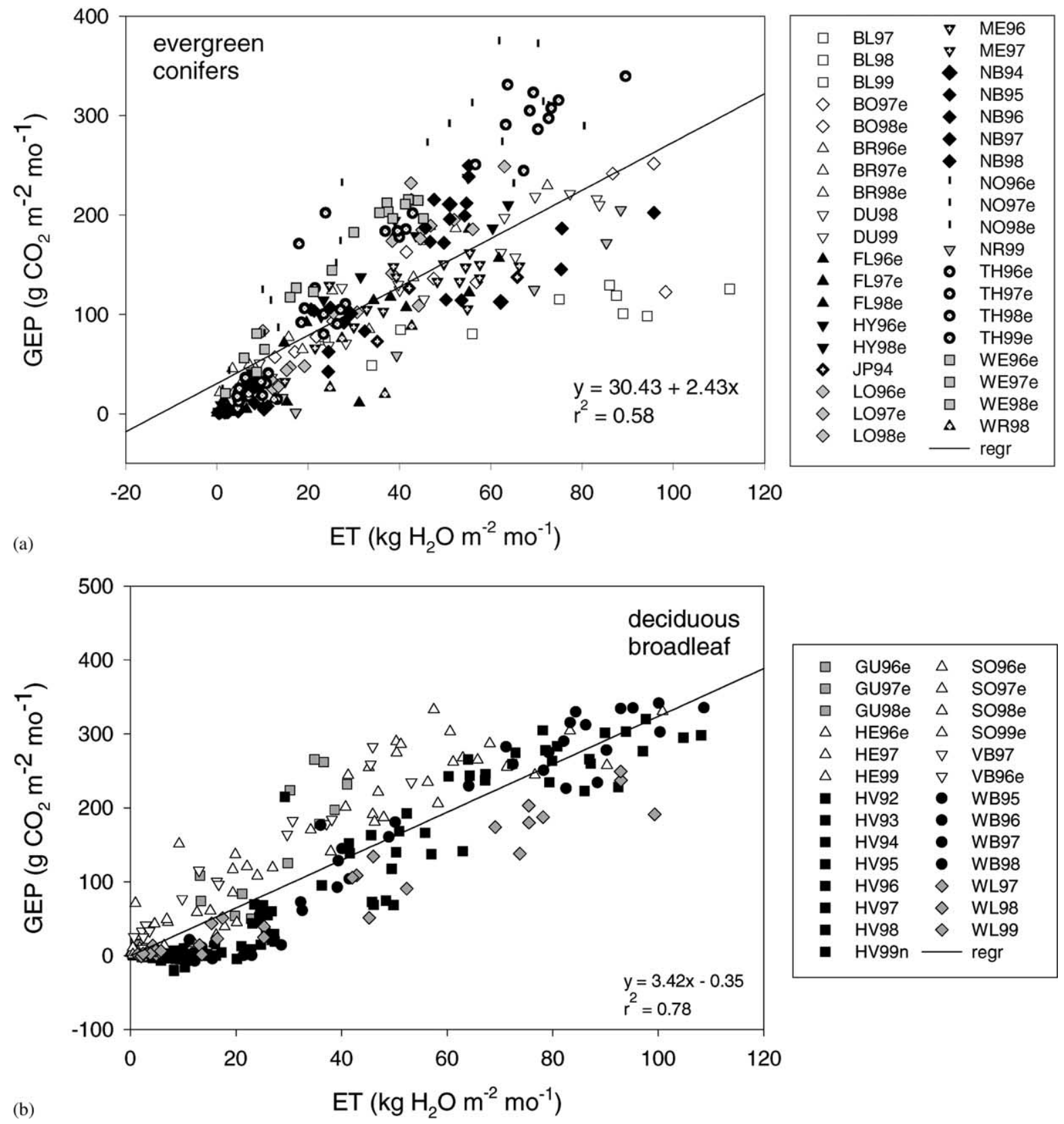

Fig. 6. Monthly GEP increased with ET in: (a) evergreen coniferous forests, where black symbols are boreal forests; (b) deciduous broadleaf forests, where gray symbols are poplar, white symbols are beech, and black symbols are oak/maple; (c) grasslands and croplands. (d) The correlation was weaker for tundra vegetation. (e) Pooled data show that the slope was similar across biomes. 

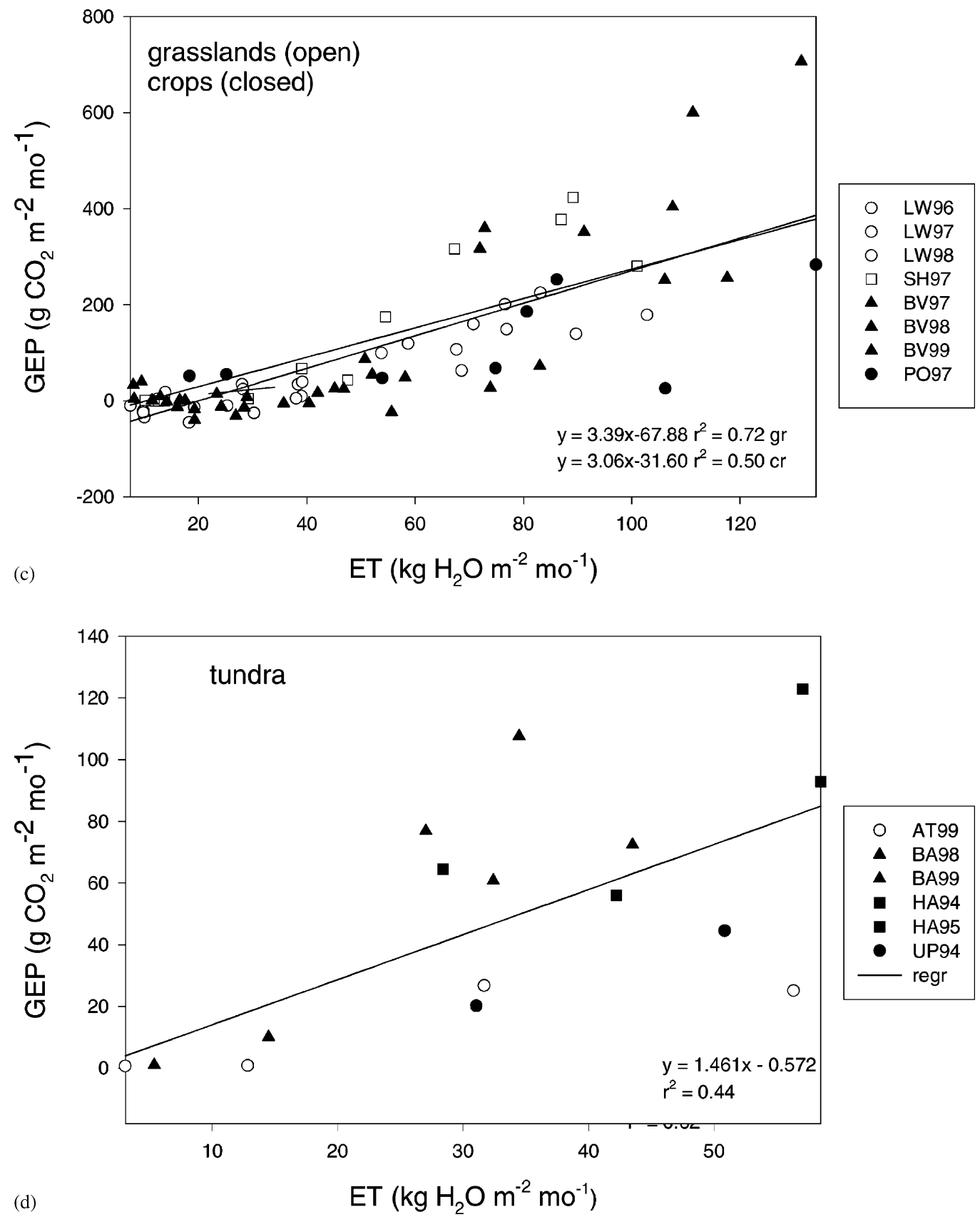

Fig. 6. (Continued).

that when LAI is less than about 5-6, canopy transpiration is proportional to LAI (Granier et al., 2000b). For a subset of flux sites at which we measured aboveand below-canopy ET, the proportion of total ET that evaporated from the forest floor increased as leaf area decreased (Fig. 7). Applying the CANVEG process model, which includes turbulent transport, radiative transfer, and a biochemical model of photosynthesis, 


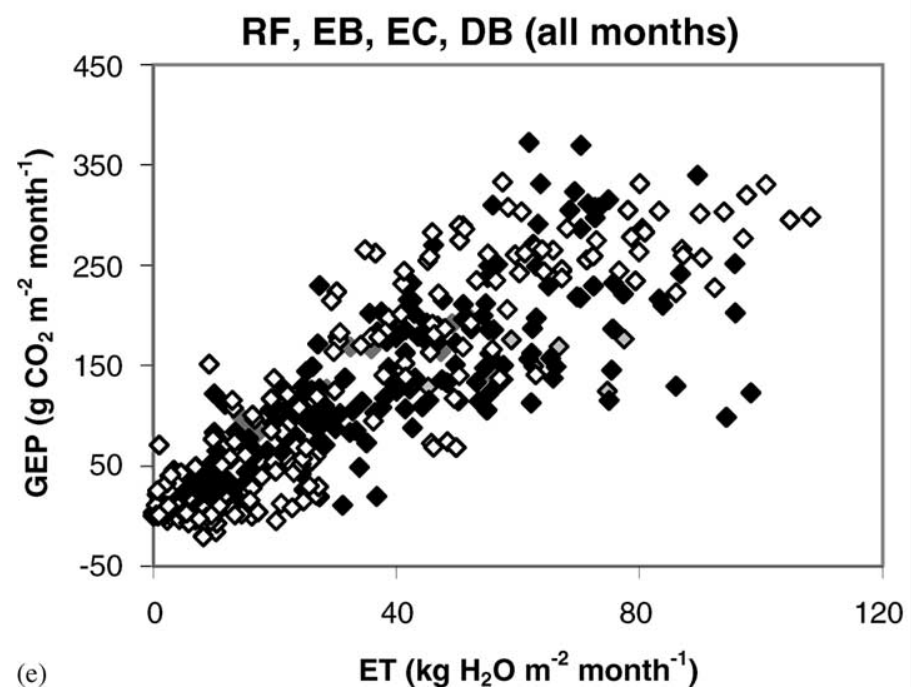

\begin{tabular}{|c|c|}
\hline $\begin{array}{l}\text { MA96 } \\
\text { CP98e } \\
\text { NB95 } \\
\text { NB97 } \\
\text { WR998 } \\
\text { BL98 } \\
\text { ME97 } \\
\text { DU97 } \\
\text { DU99 } \\
\text { BO97e } \\
\text { BR96e } \\
\text { BR98e } \\
\text { FL97e } \\
\text { HY97e } \\
\text { HY99e } \\
\text { LO97e } \\
\text { NO96e } \\
\text { NO98e } \\
\text { TH98e } \\
\text { WE97e } \\
\text { owB96 } \\
\text { o WB98 } \\
\text { o GU97e } \\
\text { o HE96e } \\
\text { b HE98n } \\
\text { o SO96e } \\
\text { S SO98e } \\
\text { o VB96e } \\
\text { o HV92n } \\
\text { o HV94n } \\
\text { o HV96n }\end{array}$ & 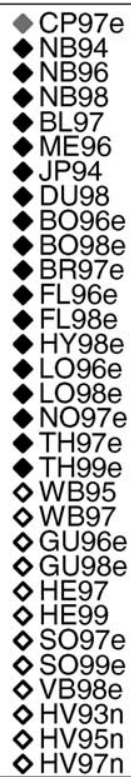 \\
\hline
\end{tabular}

Fig. 6. (Continued).

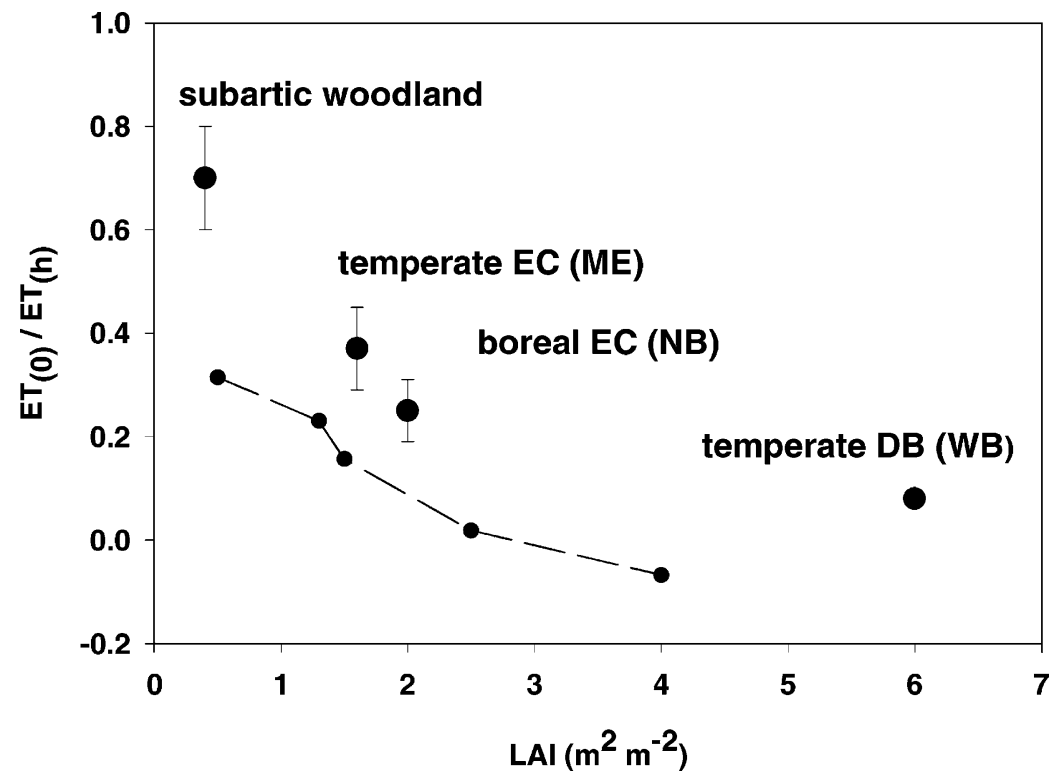

Fig. 7. The proportion of total ET that was evaporation from soil surfaces increased as LAI decreased. Site symbols, defined in Table 1 are given in parenthesis. Vegetation types include a temperate evergreen coniferous forest (EC), a boreal evergreen forest (EC), and a temperate deciduous broadleaf forest (DB). The ET and LAI values for Walker Branch (WB) were calculated from summer values at full leaf (Wilson et al., 2000b). 
resulted in a similar relationship for the ponderosa pine site (Law et al., 2001b). Although this is not a functional relationship, it is useful to demonstrate that it can be inappropriate to model evaporation as a con- stant fraction of precipitation or of total ET throughout the year.

Monthly ecosystem WUE, calculated from GEP divided by ET, decreased with increasing VPD in the

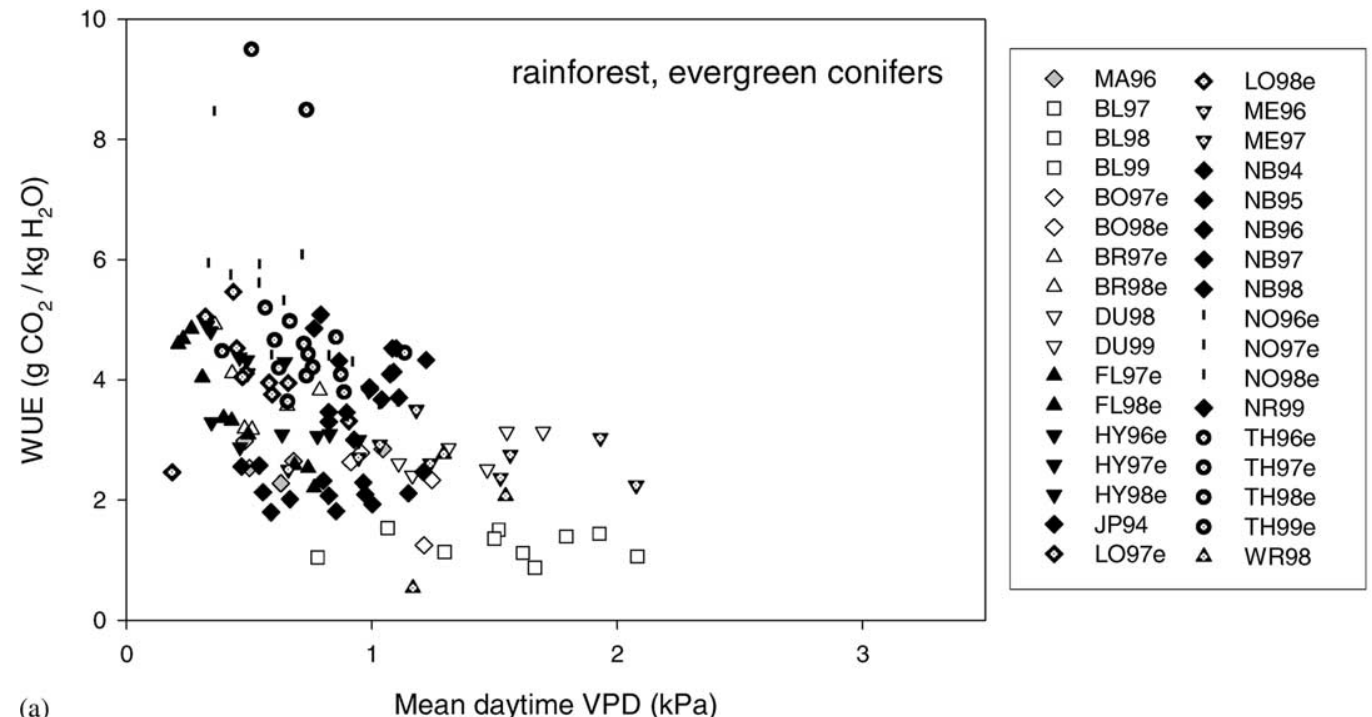

(a)
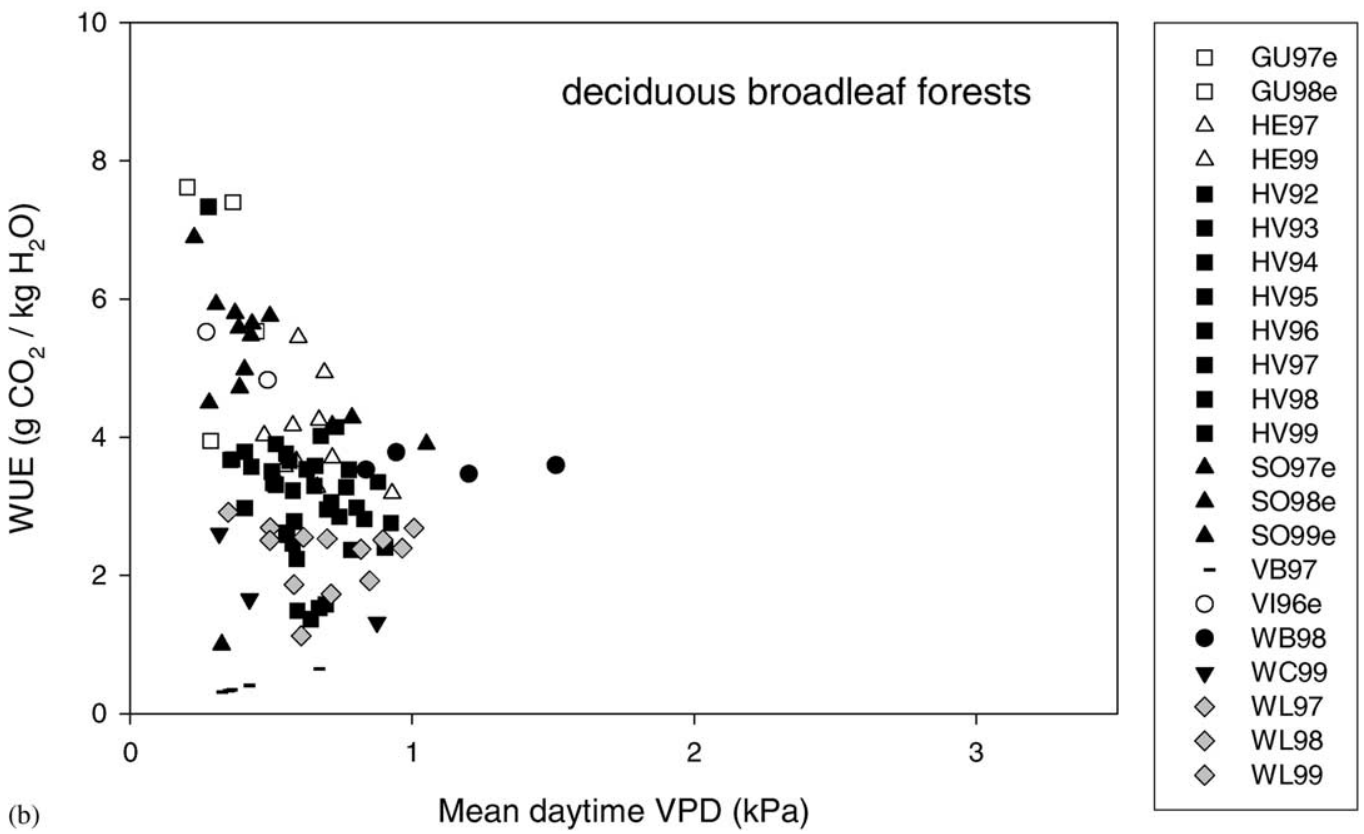

Fig. 8. (a) Monthly water use efficiency (WUE $=\mathrm{GEP} / \mathrm{ET}$ in $\mathrm{g} \mathrm{CO}_{2} / \mathrm{kg} \mathrm{H}_{2} \mathrm{O}$ ) decreased as mean daytime VPD increased in May-September for evergreen coniferous forests (boreal forests: black symbols), and in October-March in a rainforest. (b) Monthly WUE versus mean monthly VPD in deciduous broadleaf forests, and (c) crops (CR) and grasslands (GR). 


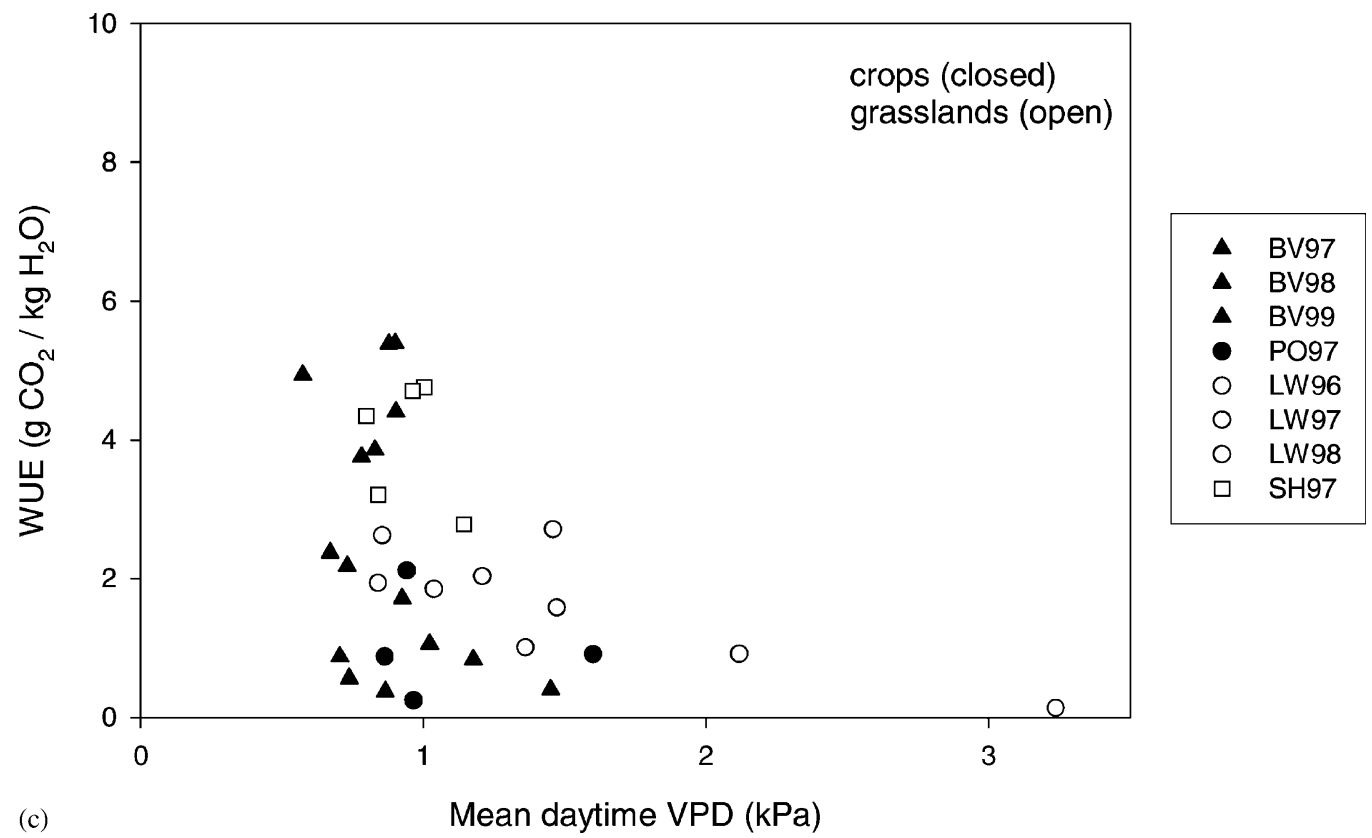

Fig. 8. (Continued)

summer months (May-September; Fig. 8), but the relation was not as strong for deciduous broadleaf forests (e.g., HV; see Table 1) and a boreal forest (NB; see Table 1), which did not experience VPD values as high as those of other vegetation types. Crops and grasslands were not as efficient as forests at high VPD, as previous studies suggested (Richards and Condon, 1993; Jones, 1992). Weekly means for all sites from May to September showed that WUE reached consistently low values at VPD greater than $\sim 1.5 \mathrm{kPa}$. At a semi-arid ponderosa pine site (ME; see Table 1), we found that daily ET varied little in summer $(\sim 1.6-1.7 \mathrm{~mm}$ per day), yet GEP decreased by about $1 \mathrm{~g} \mathrm{C}$ per day with $1 \mathrm{kPa}$ increase in mean daytime VPD (Anthoni et al., 1999). Although leaf-level experiments indicate that stomatal closure causes a proportionately greater decrease in transpiration than in photosynthesis because of additional diffusive resistances of $\mathrm{CO}_{2}$ (Cowan, 1982), other studies suggest that when water availability or hydraulic capacity of the whole plant system is limited, stomata adjust to maintain a sustainable water flow and minimize the possibility of xylem cavitation (Mencuccini and Grace, 1996), thereby reducing photosynthesis. This could explain why GEP decreased more than ET at high VPD. Goulden et al. (1997) and Jarvis et al. (1997) found little to no response of GEP to VPD in boreal coniferous forests. At the NB boreal coniferous forest (Table 1), Goulden et al. (1997) observed that the seasonal trends in photosynthesis over 3 years of measurements appeared to be influenced more by phenology than by short-term changes in environmental conditions. Thus, the general trend of decreasing WUE with increasing VPD is limited to the summer growing season for temperate vegetation, whereas temperature and phenology dominate responses in colder climates and during the rest of the year in other regions.

\section{Conclusions}

We evaluated GEP, NEE, $R_{\mathrm{e}}$, and LE at temporal scales of weeks, months, and years for sites representing different biomes. Although these responses to climate are relatively short-term, they include the effects of long-term climatic conditions and land use on vegetation type and LAI.

Ecosystem respiration was poorly correlated with mean annual temperature and mean growing season 
temperature, even though studies at individual sites showed strong correlations with temperature at shorter temporal scales, and respiration within vegetation type was sensitive to temperature on a monthly scale. Annual GEP was more sensitive to annual temperature than to site water balance, which controls the potential leaf area available for photosynthesis over the long-term, as observed along strong climatic gradients. The slope of the relation between monthly GEP and ET was very similar across vegetation types, however, indicating that physiological processes controlling water loss during carbon uptake reach a sustainable balance through the year. Perhaps this phenomenon is also influenced at the ecosystem level by competition for resources (e.g., self-thinning law in forests, whereby competition for resources limits plant density to a sustainable level).

Studies suggest that disturbance history has a large effect on NEE, compared with inter-annual differences in climate or differences in atmospheric $\mathrm{CO}_{2}$ (Thornton et al., 2002; Law et al., 2001c; Cohen et al., 1996; Grier and Logan, 1977). Thus, it is important to evaluate the influence of processes on net carbon uptake in terms of developmental stage and disturbance history over longer time frames. Studies addressing this issue are in progress as part of FLUXNET (e.g., CarboAge in Europe; studies in Oregon, North Carolina, and California).

\section{Acknowledgements}

We thank the numerous scientists, students, and technicians involved in data collection and analysis at the FLUXNET sites; the agencies that fund the projects (European Union, US Department of Energy Office of Biological and Environmental Research (DOE/BER), National Aeronautics and Space Administration (NASA), and the Multi-agency Program on Terrestrial Ecology for Global Change (TECO)); and the program managers and directors involved in FLUXNET, including Roger Dahlman, Jerry Elwood, and Ruth Reck (US DOE), and Diane Wickland (NASA). The FLUXNET data archive provided the half-hourly data sets containing information on site characteristics for our analyses.

\section{References}

Anthoni, P.M., Law, B.E., Unsworth, M.H., 1999. Carbon and water vapor exchange of an open-canopied ponderosa pine ecosystem. Agric. For. Meteorol. 95, 115-168.

Aubinet, M., Grelle, A., Ibrom, A., Rannik, Ü., Moncrieff, J., Foken, T., Kowalski, A.S., Martin, P.H., Berbigier, P., Bernhofer, Ch., Clement, R., Elbers, J., Granier, A., Grunwald, T., Morgenstern, K., Pilegaard, K., Rebmann, C., Snuders, W., Valentini, R., Vesala, T., 2000. Estimates of the annual net carbon and water exchange of forests: the EUROFLUX methodology. Adv. Ecol. Res. 30, 113-175.

Baldocchi, D.D., Vogel, C.A., Hall, B., 1997. Seasonal variation of carbon dioxide exchange rates above and below a boreal jack pine forest. Agric. For. Meteorol. 83, 147-170.

Baldocchi, D.D., Falge, E., Gu, L., Olson, R., Hollinger, D., Running, S., Anthoni, P., Bernhofer, Ch., Davis, K., Fuentes, J., Goldstein, A., Katul, G., Law, B.E., Lee, X., Mahli, Y., Meyers, T., Munger, W., Oechel, W., Paw U, K.T., Pilegaard, K., Schmid, H.P., Valentini, R., Verma, S., Vesala, T., Wilson, K., Wofsy, S.W., 2001. FLUXNET: A new tool to study the temporal and spatial variability of ecosystem-scale carbon dioxide, water vapor and energy flux densities. Bull. Am. Meteorol. Soc. 82, 2415-2434.

Berger, B.W., Davis, K.J., Bakwin, P.S., Yi, C., Zhao, C., 2001. Long-term carbon dioxide fluxes from a very tall tower in a northern forest: flux measurement methodology. J. Atmos. Ocean. Technol. 18, 529-542.

Black, A., Kelliher, F.M., 1989. Processes controlling understorey evapotranspiration. In: Jarvis, P.J., Monteith, J.L., Shuttleworth, W.J., Unsworth, M.H. (Eds.), Forests, Weather, and Climate, Royal Society of London, UK, pp. 37-57.

Bowling, D.R., McDowell, N.G., Bond, B.J., Law, B.E., Ehleringer, J.R., 2002. 13C content of ecosystem respiration is linked to precipitation and vapor pressure deficit. Oecologia. 131, 113-124.

Brooks, A., Farquhar, G., 1985. Effect of temperature on the $\mathrm{CO}_{2} / \mathrm{O}_{2}$ specificity of ribulose-1,5-bisphosphate carboxylase/ oxygenase and the respiration in the light. Planta 165, 397-406.

Budyko, M.I., 1984. Evaporation Under Natural Conditions. GIMIZ, Leningrad. IPST Translation, Jerusalem, 1963, 130 pp.

Chen, J., Falk, M., Euskirchen, E., Paw U, K.T., Suchanek, T.H., Ustin, S.L., Bond, B.J., Brosofke, K.D., Phillips, N., Rucheng, B., 2002. Tree Physiol. 22, 169-177.

Cohen, W.B., Harmon, M.E., Wallin, D.O., Fiorella, M., 1996. Two decades of carbon flux from forests of the Pacific Northwest. Bioscience 46, 836-844.

Cowan, I.R., 1977. Stomatal behavior and environment. Adv. Bot. Res. 4, 117-228.

Cowan, I.R., 1982. Regulation of water use in relation to carbon gain in higher plants. Encycl. Plant Physiol. 12B, 489-613.

Cramer, W., Bondeau, A., Woodward, F.I., Prentice, I.C., Betts, R.A., Brovkin, V., Cox, P.M., Fisher, V., Foley, J.A., Friend, A.D., Kucharik, C., Lomas, M.R., Ramankutty, N., Sitch, S., Smith, B., White, A., Young-Molling, C., 2001. Global response of terrestrial ecosystem structure and function to $\mathrm{CO}_{2}$ and climate change: results from six dynamic global vegetation models. Glob. Change Biol. 7, 357-373. 
Eugster, W., Siegrist, F., 2000. The influence of nocturnal $\mathrm{CO}_{2}$ advection on $\mathrm{CO}_{2}$ flux measurements. Basic Appl. Ecol. 1, 177-188.

Falge, E., Baldocchi, D.D., Olson, R.J., Anthoni, P., Aubinet, M., Bernhofer, C., Burba, G., Ceulemans, R., Clement, R., Dolman, H., Granier, A., Gross, P., Grünwald, T., Hollinger, D., Jensen, N.-O., Katul, G., Keronen, P., Kowalski, A., Ta Lai, C., Law, B.E., Meyers, T., Moncrieff, J., Moors, E., Pilegaard, K., Rannik, Ü., Rebmann, C., Suyker, A., Tenhunen, J., Tu, K., Verma, S., Vesala, T., Wilson, K., Wofsy, S., 2001. Gap filling strategies for defensible annual sums of net ecosystem exchange. Agric. For. Meteorol. 107, 43-69.

Falge, E., Tenhunen, J., Baldocchi, D.D., Aubinet, M., Bakwin, P., Berbigier, P., Bernhofer, C., Bonnefond, J.-M., Burba, G., Clement, R., Davis, K.J., Elbers, J.A., Falk, M., Goldstein, A.H., Grelle, A., Granier, A., Grünwald, T., Guomundsson, J., Hollinger, D., Janssens, I.A., Keronen, P., Kowalski, A.S., Katul, G., Law, B.E., Malhi, Y., Meyers, T., Monson, R.K., Moors, E., Munger, J.W., Oechel, W., Paw U, K.T., Pilegaard, K., Rannik, Ü., Rebmann, C., Suyker, A., Thorgeirsson, H., Tirone, G., Turnipseed, A., Wilson, K., Wofsy, S., 2002. Phase and amplitude of ecosystem carbon release and uptake potentials as derived from FLUXNET measurements. Agric. For. Meteorol. 113, 75-95.

Farquhar, G.D., Sharkey, T.D., 1982. Stomatal conductance and photosynthesis. Ann. Rev. Plant Physiol. 33, 317-345.

Fitzjarrald, D.R., Moore, K.E., Sakai, R.K., Freedman, J.M., 1995. Assessing the impact of cloud cover on carbon uptake in the northern boreal forest. In: Proceedings of the AGU Meeting, Spring 1995, Paper H32E-5, S215, EOS Supplement, April 25, 1995 , p. S125.

Gholz, H.L., 1982. Environmental limits on aboveground net primary production, leaf area, and biomass in vegetation zones of the Pacific Northwest. Ecology 63, 469-481.

Giardina, C.P., Ryan, M.G., 2000. Evidence that decomposition rates of organic carbon in mineral soil do not vary with temperature. Nature 404, 858-860.

Goulden, M.L., Munger, J.W., Fan, S.-M., Daube, B.C., Wofsy, S.C., 1996a. Exchange of carbon dioxide by a deciduous forest: response to interannual climate variability. Science 271,1576 1578.

Goulden, M.L., Munger, J.W., Fan, S.-M., Daube, B.C., Wofsy, S.C., 1996b. Measurements of carbon sequestration by long-term eddy covariance: methods and a critical evaluation of accuracy. Glob. Change Biol. 2, 169-182.

Goulden, M.L., Daube, B.C., Fan, S.-M., Sutton, D.J., Bazzaz, A., Munger, J.W., Wofsy, S.C., 1997. Physiological responses of a black spruce forest to weather. J. Geophys. Res. 102, 2898728996.

Goulden, M.L., Wofsy, S.C., Harden, J.W., Trumbore, S.E., Crill, P.M., Gower, S.T., Fires, T., Daube, B.C., Fan, S.-M., Sutton, D.J., Bazzaz, A., Munger, J.W., 1998. Sensitivity of boreal forest carbon balance to soil thaw. Science 279, 214-217.

Grace, J., Rayment, M., 2000. Respiration in the balance. Nature 404, 819-820.

Granier, A., Ceschia, E., Damesin, C., Dufrêne, E., Epron, D., Gross, P., Lebaube, S., Le Dantec, V., Le Goff, N., Lemoine,
D., Lucot, E., Ottorini, J.M., Pontailler, J.Y., Saugier, B., 2000a. The carbon balance of a young beech forest. Funct. Ecol. 14, 312-325.

Granier, A., Loustau, D., Bréda, N., 2000b. A generic model of forest canopy conductance dependent on climate, soil water availability and leaf area index. Ann. For. Sci. 57, 755-765.

Grelle, A., 1997. Long-term water and carbon dioxide fluxes from a boreal forest. Ph.D. Thesis, Swedish University of Agricultural Sciences, Uppsala, Sweden, 79 pp.

Grier, C.C., Logan, R.S., 1977. Old-growth Pseudotsuga menziesii communities of a western Oregon watershed: biomass distribution and production budgets. Ecol. Monogr. 47, 373400.

Grier, C.C., Running, S.W., 1977. Leaf area of mature northwestern coniferous forests: relation to site water balance. Ecology 58, 893-899.

Gu, L., Fuentes, J.D., Shugart, H.H., Staebler, R.M., Black, T.A., 1999. Responses of net ecosystem exchanges of carbon dioxide to changes in cloudiness: results from two north American deciduous forests. J. Geophys. Res. 104, 31421-31434.

Gu, L., Baldocchi, D.D., Verma, S.B., Black, T.A., Vesala, T., Falge, E.M., Dowty, P.R., 2001a. Advantages of diffuse radiation for terrestrial ecosystem productivities. J. Geophys. Res. 107 (D6), ACL2-1 to 2-23.

Gu, L., Fuentes, J.D., Garstang, M., da Silva, J.T., Heitz, R., Sigler, J., Shugart, H.H., 2001b. Cloud modulation of surface solar irradiance at a pasture site in southern Brazil. Agric. For. Meteorol. 106, 117-129.

Hassika, P., Berbigier, P., 1998. Annual cycle of photosynthetically active radiation in maritime pine forest. Agric. For. Metereol. 90, 157-171.

Hollinger, D.Y., Kelliher, F.M., Byers, J.N., Hunt, J.E., 1994. Carbon dioxide exchange between an undisturbed old-growth temperate forest and the atmosphere. Ecology 75, 134-150.

Hollinger, D.Y., Goltz, S.M., Davidson, E.A., Lee, J.T., Tu, K., Valentine, H.T., 1999. Seasonal patterns and environmental control of carbon dioxide and water vapour exchange in an ecotonal boreal forest. Glob. Change Biol. 5, 891-902.

Janssens, I.A., Lankreijer, H., Matteucci, G., Kowalski, A.S., Buchmann, N., Epron, D., Pilegaard, K., Kutsch, W., Longdoz, B., Grunwald, T., Montagnani, L., Dore, S., Rebmann, C., Moores, E.J., Grelle, A., Rannik, Ü., Morgenstern, K., Oltchev, S., Clement, R., Gudmundsson, J., Minerbi, S., Berbigier, P., Ibrom, A., Moncrieff, J., Aubinet, M., Bernhofer, C., Jensen, N.O., Vesala, T., Granier, A., Schulze, E.-D., Lindroth, A., Dolman, A.J., Jarvis, P.G., Ceulemans, R., Valentini, R., 2001. Productivity overshadows temperature in determining soil and ecosystem respiration across European forests. Glob. Change Biol. 7, 269-278.

Jarvis, P.G., Massheder, J.M., Hale, S.E., Moncrieff, J.B., Rayment, M., Scott, S.L., 1997. Seasonal variation of carbon dioxide, water vapor, and energy exchanges of a boreal black spruce forest. J. Geophys. Res. 102, 28953-28966.

Jones, H.G., 1992. Plants and Microclimate: A Quantitative Approach to Environmental Plant Physiology, second ed. Cambridge University Press, UK, 428 pp.

Kelliher, F.M., Whitehead, D., McAneney, K.J., Judd, M.J., 1990. Partitioning evapotranspiration into tree and understorey 
components in two young Pinus radiata D. Don stands. Agric. For. Meteorol. 50, 211-227.

Kozlowski, T.T., Kramer, P.J., Pallardy, S.G., 1991. The Physiological Ecology of Woody Plants. Academic Press, San Diego, USA, 390 pp.

Lafleur, P.M., Renzetti, A.V., Bello, R., 1993. Seasonal changes in the radiation balance of subarctic forest and tundra. Arct. Alp. Res. 25, 32-36.

Lavigne, M.B., Ryan, M.G., Anderson, D.E., Baldocchi, D.D., Crill, P.M., Fitzjarrald, D.R., Goulden, M.L., Gower, S.T., Massheder, J.M., McCaughey, J.H., Rayment, M., Striegl, R.G., 1997. Comparing nocturnal eddy covariance measurements to estimates of ecosystem respiration made by scaling chamber measurements at six coniferous boreal sites. J. Geophys. Res. 102, 28977-28985.

Law, B.E., Waring, R.H., 1994. Combining remote sensing and climatic data to estimate net primary production across Oregon. Ecol. Appl. 4, 717-728.

Law, B.E., Baldocchi, D.D., Anthoni, P.M., 1999a. Below-canopy and soil $\mathrm{CO}_{2}$ fluxes in a ponderosa pine forest. Agric. For. Meteorol. 94, 171-188.

Law, B.E., Ryan, M.G., Anthoni, P.M., 1999b. Seasonal and annual respiration of a ponderosa pine ecosystem. Glob. Change Biol. $5,169-182$.

Law, B.E., Williams, M., Anthoni, P., Baldocchi, D.D., Unsworth, M.H., 2000. Measuring and modeling seasonal variation of carbon dioxide and water vapor exchange of a Pinus ponderosa forest subject to soil water deficit. Glob. Change Biol. 6, 613630.

Law, B.E., Thornton, P.E., Irvine, J., Anthoni, P.M., Van Tuyl, S., 2001a. Carbon storage and fluxes in ponderosa pine forests at different developmental stages. Glob. Change Biol. 7, 755-777.

Law, B.E., Cescatti, A., Baldocchi, D.D., 2001b. Leaf area distribution and radiative transfer in open-canopy forests: implications to mass and energy exchange. Tree Physiol. 21, 777-787.

Law, B.E., Goldstein, A.H., Anthoni, P.M., Panek, J.A., Unsworth, M.H., Bauer, M.R., Fracheboud, J.M., Hultman, N., 2001c. $\mathrm{CO}_{2}$ and water vapor exchange by young and old ponderosa pine ecosystems during a dry summer. Tree Physiol. 21, 299-308.

Law, B.E., Kelliher, F.M., Baldocchi, D.D., Anthoni, P.M., Irvine, J., Moore, D., Van Tuyl, S., 2001d. Spatial and temporal variation in respiration in a young ponderosa pine forest during a summer drought. Agric. For. Meteorol. 110, 27-43.

Lieth, H., 1972a. Computer mapping of forest data. In: Proceedings of the 51st Ann. Mtg, Apppalachian Sect. of the Soc. of Amer. Foresters, pp. 53-79.

Lieth, H., 1972b. Modeling the primary productivity of the world. Tropical Ecol. 13, 125-130.

Lindroth, A., Grelle, A., Moren, A.S., 1998. Long-term measurements of boreal forest carbon balance reveal large temperature sensitivity. Glob. Change Biol. 4, 443-450.

Liski, J., Ilvesniemi, H., Makela, A., Westman, C.J., 1999. CO $_{2}$ emissions from soil in response to climatic warming are overestimated - the decomposition of old soil organic matter is tolerant of temperature. Ambio 28, 171-174.

Lloyd, J., Taylor, J.A., 1994. On the temperature dependence of soil respiration. Funct. Ecol. 8, 315-323.
Markkanen, T., Rannik, Ü., Keronen, P., Suni, T., Vesala, T., 2001. Eddy covariance fluxes over a boreal Scots pine forest, Boreal Environ. Res. 6, 65-78.

Massman, W.J., Lee, X., 2002. Eddy covariance flux corrections and uncertainties in long term studies of carbon and energy exchanges. Agric. For. Meteorol. 113, 121-144.

Mencuccini, M., Grace, J., 1996. Hydraulic conductance, light interception and needle nutrient concentration in Scots pine stands and their relations with net primary productivity. Tree Physiol. 16, 459-468.

Meyers, T.P., 2001. A comparison of summertime water and $\mathrm{CO}_{2}$ fluxes over rangeland for well watered and drought conditions. Agric. For. Meteorol. 106, 205-214.

Moncrieff, J., Malhi, Y., Leuning, R., 1996. The propagation of errors in long-term measurements of land atmosphere fluxes of carbon and water. Glob. Change Biol. 2, 231-240.

Monson, R.K., Turnipseed, A.A., Sparks, J.P., Harley, P.C., Denton-Scott, L.A., Sparks, K., Huxman, T., 2002. Carbon sequestration in a high-elevation coniferous forest. Glob. Change Biol. 8, 459-478.

Nobel, P., 1991. Physicochemical and Environmental Plant Physiology. Academic Press, San Diego, pp. 439-442.

O'Neill, R.V., DeAngelis, D.L., 1981. Comparative productivity and biomass relations of forest ecosystems. In: Reichle, D.E. (Ed.), Dynamic Properties of Forest Ecosystems. Cambridge University Press, Cambridge, pp. 411-449.

Oechel, W.C., Lawrence, W.T., 1985. Tiaga. In: Chabot, B.F., Mooney, H.A. (Eds.), Physiological Ecology of North American Plant Communities. Chapman \& Hall, New York, pp. 66-94.

Oechel, W.C., Vourlitis, G.L., Hastings, S.J., Zulueta, R.C., Hinzman, L., Kane, D., 2000. Acclimation of ecosystem $\mathrm{CO}_{2}$ exchange in the Alaskan Arctic in response to decadal climate warming. Nature 406, 978-981.

Oke, T.R., 1978. Boundary Layer Climates, second ed. Routledge, London, pp. 26-27.

Pilegaard, K., Hummelshoej, P., Jensen, N.O., Chen, Z., 2001. Two years of continuous $\mathrm{CO}_{2}$ eddy-flux measurements over a Danish beech forest. Agric. For. Meteorol. 107, 29-41.

Pitman, A.J., Henderson-Sellers, A., 1998. Recent progress and results from the project for the intercomparison of landsurface parameterization schemes. J. Hydrol. 213, 128-135.

Pitman, A.J., Henderson-Sellers, A., Desborough, C.E., Yang, Z.L., Abramopoulos, F., Boone, A., Dickinson, R.E., Gedney, N., Koster, R., Kowalczyk, E., Lettenmaier, D., Liang, X., Mahfouf, J.F., Noilhan, J., Polcher, J., Qu, W., Robock, A., Rosenzweig, C., Schlosser, C.A., Shmakin, A.B., Smith, J., Suarez, M., Verseghy, D., Wetzel, P., Wood, E., Xue, Y., 1999. Key results and implications from phase 1(c) of the project for intercomparison of land-surface parametrization schemes. Climate Dynam. 15, 673-684.

Richards, R.A., Condon, A.G., 1993. Challenges ahead in using carbon isotope discrimination in plant-breeding programs. In: Ehleringer, J.R., Hall, A.E., Farquhar, G.D. (Eds.), Stable Isotopes and Plant Carbon-Water Relations. Academic Press, San Diego, CA, USA, pp. 451-462.

Running, S.W., Coughlan, J.C., 1988. A general model of forest ecosystem processes for regional applications. I. Hydrologic 
balance, canopy gas exchange and primary production processes. Ecol. Model. 42, 125-154.

Ryan, M.G., 1991. A simple method for estimating gross carbon budgets for vegetation in forest ecosystems. Tree Physiol. 9, 255-266.

Sakai, R.K., Fitzjarrald, D.R., Moorem, K.E., Freedman, J.M., 1996. How do forest surface fluxes depend on fluctuating light level? In: Proceedings of the 22nd Conference on Agricultural and Forest Meteorology with Symposium on Fire and Forest Meteorology, Vol. 22, Atlanta, GA. American Meteorological Society, pp. 90-93.

Schimel, D., Melillo, J., Tian, H., McGuire, A.D., Kicklighter, D., Kittel, T., Rosenbloom, N., Running, S., Thornton, P., Ojima, D., Parton, W., Kelly, R., Sykes, M., Neilson, R., Rizzo, B., 2000. Contribution of increasing $\mathrm{CO}_{2}$ and climate to carbon storage by ecosystems in the United States. Science 287, 2004-2006

Schimel, D., Apps, M., Canadell, J., Ciais, P., Denning, S., Field, C., Friedlingstein, P., Goodale, C., Heimann, M., Hibbard, K., Houghton, R.A., House, J., Melillo, J., Moore III, B., Murdiyarso, D., Noble, I., Pacala, S., Prentice, C., Raupach, M., Rayner, P., Scholes, B., Steffen, W., 2002. The terrestrial carbon cycle: a synthesis and review. Nature, (in press).

Schulze, E.-D., Lloyd, J., Kelliher, F.M., Wirth, C., Rebmann, C., Luhker, B., Mund, M., Knohl, A., Milyukova, MI.M., Schulze, W., Ziegler, W., Varlagin, A.B., Sogachev, A.F., Valentini, R., Dore, S., Grigoriev, S., Kolle, O., Panfyorov, M.I., Tchebakova, N., Vygodskaya, N.N., 1999. Productivity of forests in the Eurosiberian boreal region and their potential to act as a carbon sink-a synthesis. Glob. Change Biol. 5, 703-722.

Schulze, E.-D., Wirth, C., Heimann, M., 2000. Managing forests after Kyoto. Science 289, 2058-2059.

Segal, M., Davis, J., 1992. The impact of deep cumulus reflection on the ground-level global irradiance. J. Appl. Meteorol. 31, 217-222.

Sellers, P.J., Hall, F.G., Kelly, R.D., Black, A., Baldocchi, D., Berry, J., Ryan, M., Ranson, K.J., Crill, P.M., Lettenmaier, D.P., Margolis, H., Cihlar, J., Newcomer, J., Fitzjarrald, D., Jarvis, P.G., Gower, S.T., Halliwell, D., Williams, D., Goodison, B., Wickland, D.E., Guertin, F.E., 1997a. BOREAS in 1997: experiment overview, scientific results, and future directions. J. Geophys. Res. 102, 28731-28769.

Sellers, P.J., Dickinson, R.E., Randall, D.A., Betts, A.K., Hall, F.G., Berry, J.A., Collatz, G.J., Denning, A.S., Mooney, H.A., Nobre, C.A., Sato, N., Field, C.B., Henderson-Sellers, A., 1997b. Modeling the exchanges of energy, water, and carbon between continents and the atmosphere. Science 275, 502-509.

Thornton, P.E., Running, S.W., 1999. An improved algorithm for estimating incident daily solar radiation from measurements of temperature, humidity, and precipitation. Agric. For. Meteorol. 93, 211-228

Thornton, P.E., Law, B.E., Ellsworth, D.S., Goldstein, A., Hollinger, D., Paw U, K.T., 2002. Modeling the effects of disturbance history and climate on carbon and water budgets in evergreen needleleaf forests. Agric. For. Meteorol. 113, $185-222$.

Valentini, R., Matteucci, G., Dolman, A.J., Schulze, E.-D., Rebmann, C., Moors, E.J., Granier, A., Gross, P., Jensen, N.O., Pilegaard, K., Lindroth, A., Grelle, A., Bernhofer, C., Grunwald, T., Aubinet, M., Ceulemans, R., Kowalski, A.S., Vesala, T., Rannik, Ü., Berbigier, P., Loustau, D., Gudmundsson, J., Thorgeirsson, H., Ibrom, A., Morgenstern, K., Clement, R., Moncrieff, J., Montagnani, L., Minerbi, S., Jarvis, P., 2000. Respiration as the main determinant of carbon balance in European forests. Nature 404, 861-865.

Vesala, T., Haataja, J., Aalto, P., Altimir, N., Buzorius, G., Garam, E., Hämeri, K., Ilvesniemi, H., Jokinen, V., Keronen, P., Lahti, T., Markkanen, T., Mäkelä, J.M., Nikinmaa, E., Palmroth, S., Palva, L., Pohja, T., Pumpanen, J., Rannik, Ü., Siivola, E., Ylitalo, H., Hari, P., Kulmala, M., 1998. Long-term field measurements of atmosphere-surface interactions in boreal forest combining forest ecology, micrometeorology, aerosol physics and atmospheric chemistry. Trends Heat Mass Moment. Trans. 4, 17-35.

Williams, M., Rastetter, E.B., Fernandes, D.N., Goulden, M.L., Shaver, G.R., Johnson, L.C., 1997. Predicting gross primary productivity in terrestrial ecosystems. Ecol. Appl. 7, 882-894.

Williams, M., Law, B.E., Anthoni, P.M., Unsworth, M.H., 2001. Use of a simulation model and ecosystem flux data to examine carbon-water interactions in ponderosa pine. Tree Physiol. 21, 287-298.

Wilson, K.B., Baldocchi, D.D., 2000a. Seasonal and interannual variability of energy fluxes over a broadleaved temperate deciduous forest in North America. Agric. For. Meteorol. 100, $1-18$.

Wilson, K.B., Hanson, P.J., Baldocchi, D.D., 2000b. Factors controlling evaporation and energy partitioning beneath a deciduous forest over an annual cycle. Agric. For. Meteorol. 102, 83-103.

Wilson, K.B., Baldocchi, D.D., Hanson, P.J., 2001. Leaf age affects the seasonal pattern of photosynthetic capacity and net ecosystem exchange of carbon in a deciduous forest. Plant Cell Environ 24, 571-583.

Wilson, K., Goldstein, A., Falge, E., Aubinet, M., Baldocchi, D., Berbigier, P., Bernhofer, C., Ceulemans, R., Dolman, H., Field, C., Grelle, A., Ibrom, A., Law, B.E., Kowalski, A., Meyers, T., Moncrieff, J., Monson, R., Oechel, W., Tenhunen, J., Valentini, R., Verma, S., 2002. Energy balance closure at FLUXNET sites. Agric For. Meteorol. 113, 223-243.

Woodward, F.I., 1987. Climate and Plant Distribution. Cambridge University Press, Cambridge, UK, pp. 19-37.

Xu, M., DeBiase, T.A., Qi, Y., Goldstein, A., Liu, Z., 2001. Ecosystem respiration in a young ponderosa pine plantation in the Sierra Nevada Mountains, California. Tree Physiol. 21, 309-318. 